Royal Ontario Museum

Life Sciences Contribution

Ecological and Behavioural Evidence for the Systematic Status of New Zealand Oystercatchers (Charadriiformes: Haematopodidae)

Allan J. Baker

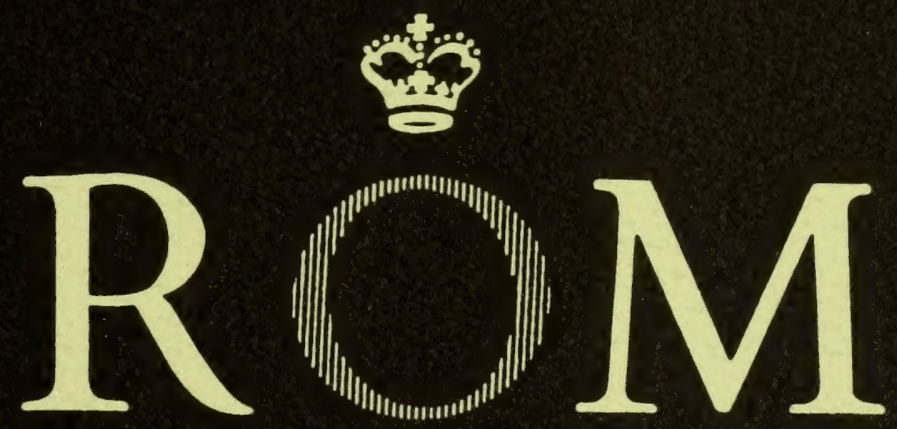


Digitized by the Internet Archive in 2011 with funding from University of Toronto 
LIFE SCIENCES CONTRIBUTIONS

ROYAL ONTARIO MUSEUM

NUMBER 96

allan J. BAKer Ecological and Behavioural Evidence for the Systematic Status of New Zealand Oystercatchers (Charadriiformes: Haematopodidae) 


\section{ROYAL ONTARIO MUSEUM \\ PUBLICATIONS IN LIFE SCIENCES}

The Royal Ontario Museum publishes three series in the Life Sciences:

LIFE SCIENCES CONTRIBUTIONS, a numbered series of original scientific publications, including monographic works.

LIFE SCIENCES OCCASIONAL PAPERS, a numbered series of original scientific publications, primarily short and usually of taxonomic significance.

LIFE SCIENCES MISCELLANEOUS PUBLICATIONS, an unnumbered series of publications of varied subject matter and format.

All manuscripts considered for publication are subject to the scrutiny and editorial policies of the Life Sciences Editorial Board, and to review by persons outside the Museum staff who are authorities in the particular field involved.

\section{LIFE SCIENCES EDITORIAL BOARD}

Chairman: R. L. PETERSON

Editor: D. BARR

Associate Editor: J. C. BARLOW

Associate Editor: J. R. TAMSITT

ALLAN J. BAKER is Assistant Curator of the Department of Ornithology, Royal Ontario Museum, and Research Associate of the Department of Zoology, University of Toronto.

PRICE : $\$ 2.00$

(C)The Royal Ontario Museum, 1974

100 Queen's Park, Toronto, Canada

PRINTED AT THE BRYANT PRESS LIMITED 


\section{Contents}

Abstract, 1

Introduction, 1

Methods, 3

Habitat Selection, 3

Niche Utilization, 5

Food Requirements, 5

Breeding Biology, 5

Parasites, 6

Vocalizations, 6

Statistical Analysis, 6

Univariate Techniques and Significance Levels, 6 Multivariate Techniques, 6

Habitat Selection, 8

Niche Utilization, 11

Food Requirements and Interspecific Competition, 14

Breeding Biology, 16

Parasites, 20

Behaviour, 20

Multivariate Assessment of Affinities, 26

Cluster Analysis, 26

Principal Component Analysis, 27

Nonmetric Multidimensional Scaling, 29

Systematic Conclusions, 30

Acknowledgments, 31

Literature Cited, 32 



\title{
Ecological and Behavioural Evidence for the Systematic Status of New Zealand Oystercatchers (Charadriiformes: Haematopodidae)
}

\begin{abstract}
Genetic isolation between the mainland New Zealand species of oystercatcher is maintained by species differences in habitat selection, niche utilization, food requirements, breeding biology and pair formation. South Island Pied Oystercatchers (Haematopus ostralegus finschi) usually feed in large flocks in estuaries and mudflats where bivalves are abundant. Variable Oystercatchers $(H$. unicolor), especially the black phase in the South Island, are sparsely distributed over rocky shores from which they take mainly limpets, chitons, and mussels. Habitat selection in mainland New Zealand species is most marked in regions of species overlap and is enhanced by competitive exclusion of $H$. unicolor from habitats with soft substrates. In such habitats, the disproportionately long and slender bill of H. o. finschi is well adapted for probing for bivalve molluscs, whereas on rocky shores the stouter and heavier bill of $H$. unicolor enables it to exploit foods unavailable to the smaller South Island bird.

In the breeding season the mainland species of oystercatcher have allopatric dispersions and largely asynchronous breeding cycles. Because pair formation occurs at different times of the year for these species, and as some South Island Pied Oystercatcher pairs are formed following migration to inland breeding sites, the mainland species are therefore effectively reproductively isolated.

The Chatham Islands Oystercatcher ( $H$. chathamensis) has dual affinities. It resembles $H$. ostralegus finschi in breeding seasons, social piping, vocalizations, and eggs. They also both lack the louse Quadraceps ridgwayi which is found on the Variable Oystercatcher. Yet the rock-dwelling, coastal breeding, and non-migratory habits of $H$. chathamensis indicate relationship with $H$. unicolor. When these affinities were subjected to multivariate analysis, both Q-mode cluster analysis and R-mode ordination techniques ordered the OTUs into three groups (species) consistent with recent classification.
\end{abstract}

\section{Introduction}

The use of ecological characters in systematic research at all levels of classification is now widespread (Selander, 1969, 1971). So important are these 
characters that Mayr, Linsley and Usinger (1953) suggested they were necessary for complete species description. Modern studies frequently adopt a biologically integrated approach to systematics, involving synthesis of pertinent morphological, ecological, and ethological information. However, as Selander (1969) has pointed out, systematists working at the species level must be careful in selecting ecological characters for comparative study, since at this level characters are of value only if they reflect mechanisms of genetic isolation.

Behaviour also provides valuable characters for systematic studies of animals. In the higher vertebrates especially, ethological differences between species commonly function as reproductive isolating mechanisms. Comparative studies of the behaviour of closely related species have led to significant improvements in the classification of some groups of birds; e.g. Moynihan (1959) and Smith (1966) on gulls, Delacour and Mayr (1945) and Johnsgard (1965) on ducks. A general review of recent contributions of behaviour to systematic studies of birds is that of Ficken and Ficken (1966).

Three species of oystercatchers are recognized in the Annotated Checklist of New Zealand birds (osNZ, 1970) (Fig. 1): Haematopus ostralegus finschi Martens, 1897-the South Island Pied Oystercatcher, a pied form with Holarctic affinities (Fleming, 1962); Haematopus unicolor Forster, 1844 the Variable Oystercatcher, which has pied, black and intermediate colour phases; and Haematopus chathamensis Hartert, 1927-the Chatham Islands Oystercatcher, which is a pied form restricted to the Chatham Islands $800 \mathrm{~km}$ East of mainland New Zealand. The nomenclature of these taxa has been subject to considerable change in this century, and they have been regarded as a taxonomically difficult group (Falla et al., 1966). Just what evidence was used in arriving at the above taxonomy is unknown, as nothing of taxonomic significance has been published on these species since the original checklist (OSNZ, 1953) appeared. The latter referred the Chatham Islands Oystercatcher to a subspecies of $H$. unicolor, so it is uncertain whether this bird should be regarded as a full species, as merely a subspecies of $H$. unicolor, or even as a subspecies of $H$. ostralegus (with which it has several morphological similarities). As a biologically integrated approach to systematics this paper presents a comparison of some aspects of the ecology and behaviour of New Zealand oystercatchers relevant to clarifying their systematic status.

\section{Methods}

\section{HABITAT SELECTION}

Many localities with contrasting substrates were visited during the course of this study. At each locality, the extent and nature of the various substrates were recorded, and preference of feeding birds for particular substrates in heterogeneous habitats was noted.

Fig. 1. New Zealand oystercatchers.

A. South Island Pied Oystercatcher (Haematopus ostralegus finschi).

B. Chatham Islands Oystercatcher (H. chathamensis).

C. Black phase Variable Oystercatcher (H. unicolor).

D. Pied phase Variable Oystercatcher (H. unicolor). 

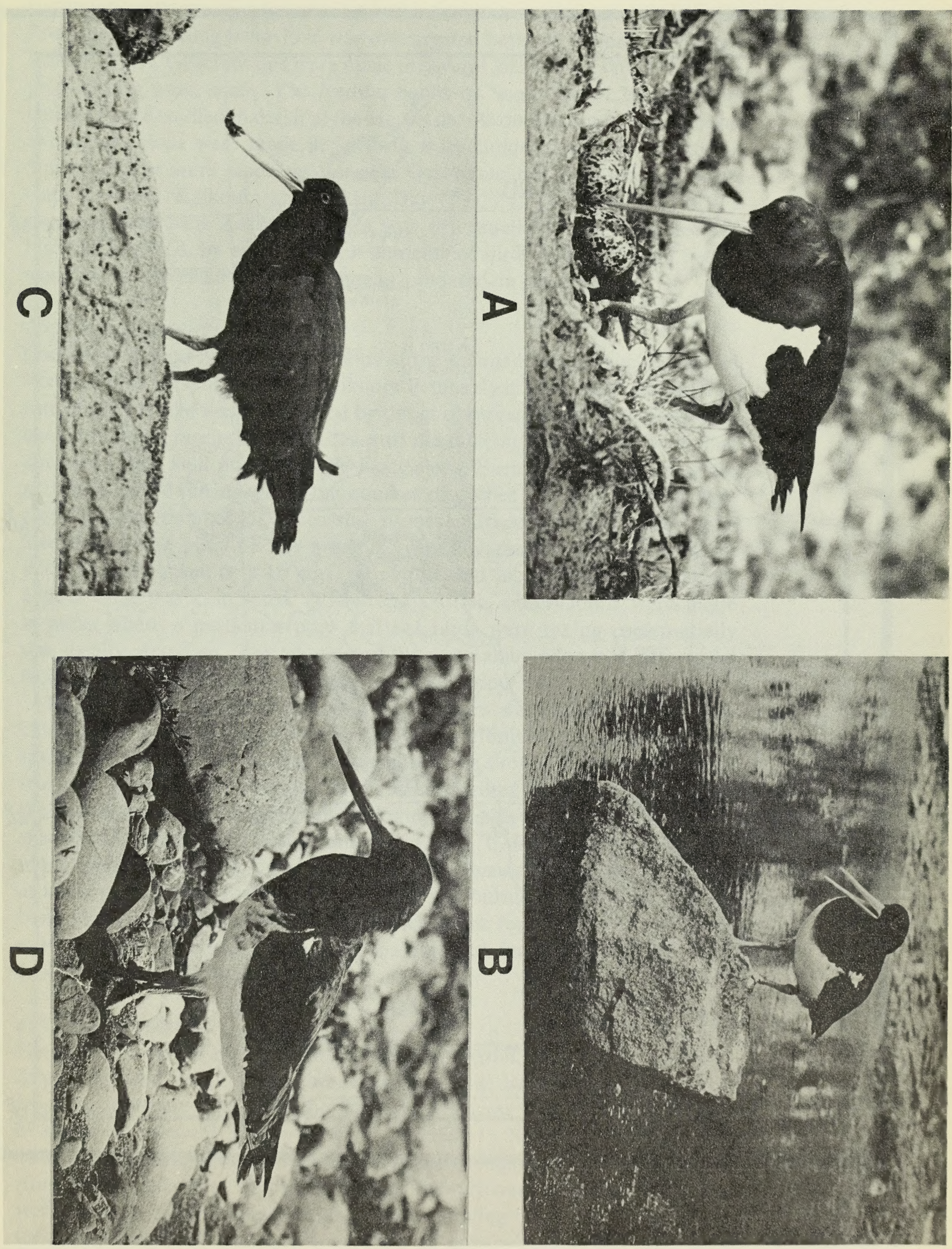


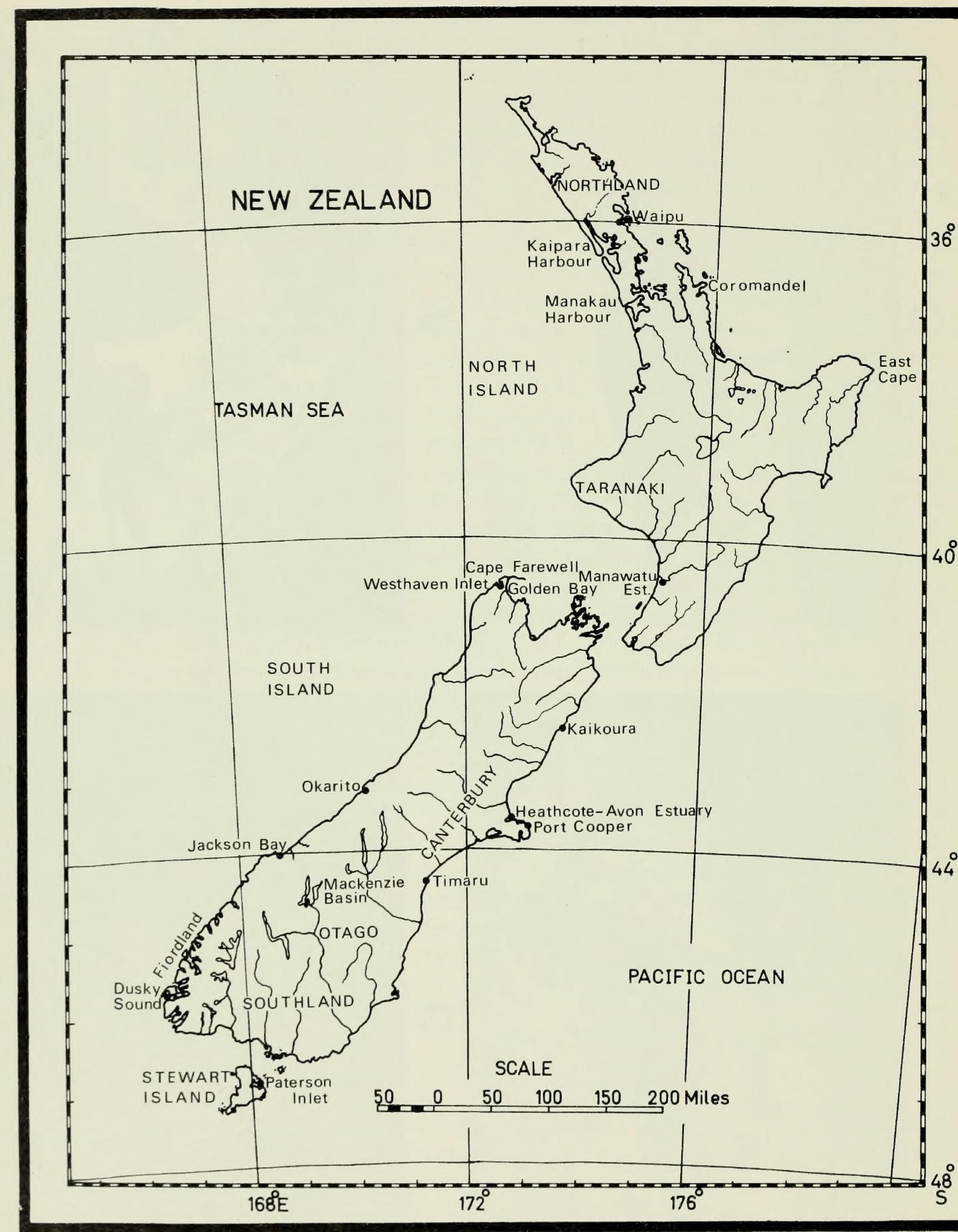

Fig. 2. Map of New Zealand showing study areas, localities and provinces mentioned in the text. 


\section{NICHE UTILIZATION}

Prey-specific feeding behaviour was investigated between January 1967 and January 1968. Observations were made at several localities in which different prey species were taken. The feeding habits of South Island Pied Oystercatchers were studied in detail at the Heathcote-Avon Estuary, and comparative observations were made at Jackson Bay, Golden Bay, and Kaikoura. Similar studies were made on Variable Oystercatchers at Westhaven Inlet, Cape Farewell, Kaikoura and Jackson Bay (Fig. 2). The winter diet of the two mainland New Zealand species was determined by watching feeding birds taking food, by examining gut contents of birds collected from netted samples, and by examining faecal smears prepared on glass slides.

\section{FOOD REQUIREMENTS}

Comparative food intake observations of the mainland oystercatcher species were made at Jackson Bay and Kaikoura Peninsula in mid-winter, 1967. The rate of food intake was determined by direct observation. Observations were confined to one bird at a time because of the difficulty of keeping more than one bird in the field of view of the fieldglasses. Each bird was observed for a $10 \mathrm{~min}$ period during which the number of probes in search of food were recorded, the number of successful probes marked, and the food taken identified where possible. To minimize observer fatigue, each observation, period was followed by a $10 \mathrm{~min}$ rest period, and the process repeated until a tidal cycle was completed. Whenever possible, observations were made in areas where a particular prey that the birds were taking preferentially was locally abundant. This eliminated the anomalous effects of differential feeding rates resulting from variation in diet (Hartley, 1948).

The daily food requirements of oystercatchers were determined by calculating the mean feeding rate per bird and multiplying by the mean time spent feeding each day. The mean weight of the prey taken was calculated from the sizes of the molluscan shells left at feeding areas. Dry weights of the food species were determined by drying samples of 30 animals of each species in a vacuum oven to constant weight at $65^{\circ} \mathrm{C}$. Calorific values of these foods were determined by grinding the dry tissues into a homogeneous mixture, compacting a sample into a pellet, and burning it in a Parr oxygenbomb calorimeter. Five samples only were burnt for each food species as even the most divergent calorific values obtained for samples of the same food differed by less than $1 \%$.

\section{BREEDING BIOLOGY}

General data on the duration of the breeding season, the time of breeding, dispersal to and from breeding areas, and breeding dispersion were gathered from the literature, and from the Recording Scheme and nest record cards of the Ornithological Society of New Zealand. In both the 1969-70 and 1970-71 breeding seasons a survey of major breeding localities was made from Stewart Island to Northland, and in early November 1970 two weeks were spent in the Chatham Islands. Many breeding birds were trapped on the nest during these surveys. They were all colour-banded and their eggs weighed and measured. 
The incidence of breeding behaviour of South Island Pied Oystercatchers over the period May to November 1967 was recorded by weekly visits to the Heathcote-Avon Estuary. During each visit the types and numbers of breeding displays were noted over one-hour observation periods. Comparative observations were made of Variable Oystercatchers at Jackson Bay, Okarito and Northland, between May to August 1970.

\section{PARASITES}

Mallophaga were collected from live-trapped oystercatchers of all three species by searching through the plumage with fine forceps. More comprehensive collections of lice were obtained by stripping the plumage from freshly dead birds and boiling it in a $3 \%$ solution of potassium hydroxide until the feathers disintegrated. Lice were recovered from the solution by sieving through a fine-meshed sieve. Ten South Island Pied Oystercatchers, four Variable Oystercatchers, and one Chatham Islands Oystercatcher were treated in this manner. Helminths were obtained from the guts of birds collected from netted samples.

\section{VOCALIZATIONS}

Vocalizations of courting birds were recorded in the field using a FI-CORD 202 tape recorder with a frequency response of 40-20,000 Hz. Recordings were made through a low impedance DP4/L Grampian microphone of similar frequency response fitted to a parabolic reflector of radius $60.96 \mathrm{~cm}$ (24 in). Several courting pairs were recorded, but only the highest quality recording for each species was selected for analysis on a KAY ELECTRIC 6061 B Sonagraph.

\section{STATISTICAL ANALYSIS}

\section{Univariate Techniques and Significance Levels}

Differences between mean dimensions and weights of eggs of the three species were tested by Student's $t$-tests of the normalized data. In all tests the significance level was set at 0.95 . Probability ranges associated with significance tests were designated by asterisks as follows:

$$
* * *=P \leqslant 0.001, * *=P \leqslant 0.01, *=P \leqslant 0.05, \mathrm{~ns}=P>0.05 .
$$

\section{Multivariate Techniques}

The assessment of phenetic affinities of closely related taxa using multiple characters is particularly appropriate to multivariate statistical techniques, which consider variation in the characters simultaneously. For numerical analysis, ecological and behavioural characters were coded into 23 two-state characters (Table 1) over 5 OTUs (Operational Taxonomic Units-Sokal and Sneath, 1963). Coding followed the scheme of Bonham-Carter (1967), where possession of a character is coded as 2 , absence as 1 , and no data as 0 . For heuristic purposes, the three colour phases of the Variable Oystercatcher were included as OTUs along with the South Island Pied and Chatham Islands Oystercatchers.

Both Q-mode (correlations and distances among OTUs) and R-mode (correlations among characters) analyses were performed on the coded data. Prior to correlation and distance analysis, characters were standardized 


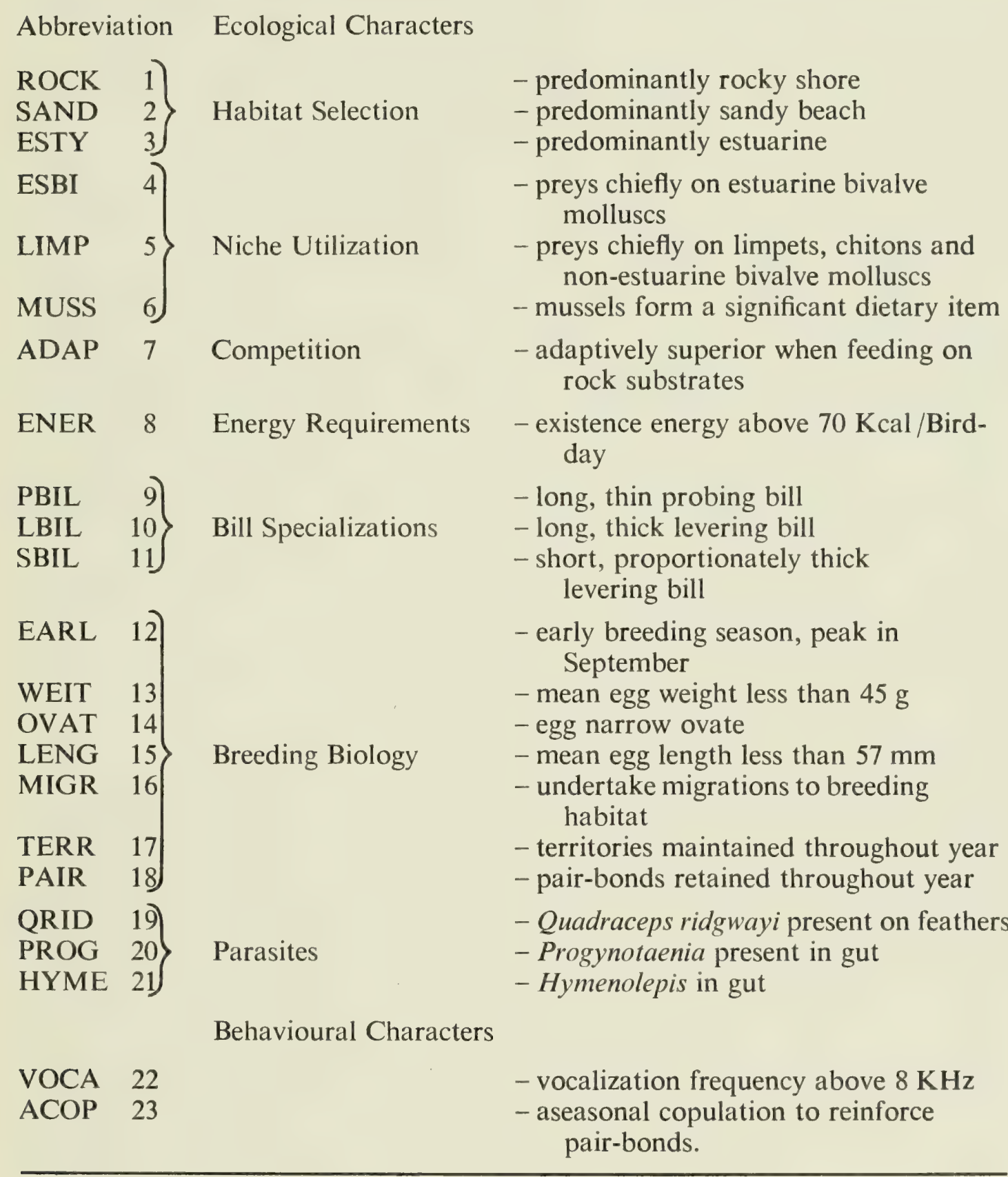

so that they had a mean of zero and a standard deviation of one. Average taxonomic distances and product-moment correlation coefficients were computed among OTUs, but as the distances actually measure dissimilarities they were converted to their 10-complements to represent similarities. The similarity coefficients were then subjected to cluster analysis, using the unweighted pair-group method on arithmetic averages (Sokal and Sneath, 1963 ). This method of clustering was chosen over others because there was no logical basis for weighting characters and because it usually gives the least distortion when represented by a two-dimensional phenogram (Sokal and Rohlf, 1962; Farris, 1969; Rohlf, 1970). Distance and correlation coefficient phenograms were compared by computing the coefficient of correlation of cophenetic values (Crovello, 1969). 
The results of cluster analysis were compared with the ordination technique of principal components analysis, which essentially reduces the variation in the original input character matrix to a few orthogonal (and thus uncorrelated) factors. This technique reduces character correlations to a simpler and more comprehensible form and also allows the investigator to estimate the importance of each character in the resulting ordination. Principal components were extracted from the matrix of correlations among the ecological and behavioural characters, the OTUs were projected onto the first three components to reveal their dispersion in 3-D space, and the loadings of characters on these components were computed.

Principal component analysis, however, has an inherent disadvantage when ecological and behavioural data are considered, because the method depends upon the assumption that each component is a linear compound of the original variables. As pointed out by Holloway and Jardine (1968) this may be a questionable assumption, so the data were also subjected to nonmetric multidimensional scaling (Kruskal, 1964) which makes no assumptions about the linearity of regression. Nonmetric scaling has the further advantage that it computes a goodness-of-fit measure (the stress) between the projections of the points in space and the original distance matrix. Stress is defined by the equation:

$$
S=\left[\frac{(d * i j-\hat{d i j})^{2}}{(d * i j-\bar{d} * i j)^{2}}\right]^{\frac{1}{2}}
$$

where $\mathrm{d}^{*} \mathrm{ij}$ is the distance between OTUs $i$ and $j$ in the reduced $k$ dimensional space, $\bar{d} * i j$ is the mean of these distances, and $\hat{d i j}$ is the expected value of $\mathrm{d} * \mathrm{ij}$ assuming a monotonic relationship between $\mathrm{d} * \mathrm{ij}$ and the original similarities. Nonmetric multidimensional scaling produces a configuration of $n$ points in a reduced space of $k$ dimensions such that the interpoint distances have a monotone relationship with the similarities among the points. For the analysis, taxonomic distances previously generated in cluster analysis were used as input data, and the OTUs were projected onto the first three dimensions. A shortest minimally connected network (Rohlf, 1970) computed from the original matrix of distances among OTUs was fitted to the 3-D projections of the OTUs in both the principal components and nonmetric scaling analyses to indicate where any distortion may have occurred in the reduced dimensionalities.

\section{Habitat Selection}

Oystercatchers are essentially coastal birds, favouring littoral feeding habitats, with only two continental subspecies (Haematopus ostralegus longipes and H. o. osculans) moving inland to utilize terrestrial habitats. In winter, New Zealand oystercatchers preferentially feed in the littoral zone of marine habitats, though in the last decade there has been an increasing tendency to feed in coastal terrestrial habitats (Baker, 1973).

South Island Pied Oystercatchers show a marked preference for feeding in habitats with soft substrates, such as estuaries, mudflats, and sandy 
beaches. In contrast, the black phase of the Variable Oystercatcher is a characteristic inhabitant of rocky shores, especially in the South Island. Black, pied and intermediate colour phases in the North Island are most often found in habitats where sandy beaches alternate with rock platforms. The decreasing use of rocky areas here probably does not indicate a change in habitat selection, but rather reflects a lessening of interspecific competition with South Island Pied Oystercatchers for sandy habitats, together with a change in habitat availability. In Northland, rocky areas are restricted in extent, and $H$. o. finschi relatively scarce compared with other areas of New Zealand. It is therefore common to see $H$. unicolor feeding on estuaries and beaches there.

Wherever South Island Pied Oystercatchers are locally abundant in areas of species overlap, Variable Oystercatchers tend to retreat to the rocky parts of the coast. The exclusion of Variable Oystercatchers from habitats with soft substrates has been documented in at least two instances. Early in this century, large flocks of black phase Variable Oystercatchers fed on the mudflats of Paterson Inlet on Stewart Island, and occasionally they were accompanied by one or two South Island Pied Oystercatchers. On 25 July 1942 eight of the latter species were seen there, and since that time they have increased their numbers steadily to their present-day population of several hundreds. During the same period Variable Oystercatchers gradually became more scarce and have tended to feed increasingly on nearby rocky habitats (R. H. Traill, pers. comm., 1970). A similar decrease in numbers of Variable Oystercatchers associated with an increase in South Island Pied Oystercatchers has been recorded at the Manawatu estuary since 1958, as shown in Table 2 (I. G. Andrew, pers. comm., 1970).

At localities where the smaller South Island bird is absent or present only in small numbers, however, its larger Variable congener usually spreads back onto beaches and estuaries adjacent to rocky parts of the coast. Hinde (1970) considered that this type of behaviour was strong evidence of competition for feeding habitats, and in such instances he noted, "When one of two closely related species which occupy different habitats within the same general area is locally absent, the other may spread to occupy both habitats" (ibid., p. 688). Thus, in regions of species overlap, direct interspecific competition for food in heterogeneous habitats is largely prevented by differential habitat selection. In homogeneous habitats, competitive exclusion is not absolute as the effects of competition are reduced by interspecific differences in niche utilization (see below).

The Chatham Islands Oystercatcher is most often found feeding in rocky habitats, though it does feed on sandy beaches close to rock platforms (Travers and Travers, 1872; personal observation, 1970). Fleming (1939) noted this habitat preference and suggested that this species was morphologically adapted to exploit rocky areas.

The selection of rocky habitats by North American Black Oystercatchers (H. bachmani) has been attributed to predator selection (Bancroft, 1927). This view contended that melanistic plumage gave protective colouration against dark rock backgrounds, whereas white-bellied forms were less conspicuous on sandy beaches. It is doubtful whether this hypothesis can account 


\section{TABLE 2 Peak winter census figures of oystercatchers at Manawatu Estuary since 1958}

\begin{tabular}{|c|c|c|}
\hline \multirow[t]{2}{*}{ Year } & \multicolumn{2}{|c|}{ Species } \\
\hline & Variable Oystercatcher & South Island Pied Oystercatcher \\
\hline 1958 & 27 & 24 \\
\hline 1959 & 31 & 25 \\
\hline 1960 & 12 & 30 \\
\hline 1961 & 8 & 36 \\
\hline 1962 & 13 & 55 \\
\hline 1963 & 18 & 66 \\
\hline $1964-66$ & \multicolumn{2}{|c|}{ No censuses made } \\
\hline 1967 & 6 & 80 \\
\hline 1968 & 4 & $\begin{array}{l}29 \text { (summer } \\
\text { census only) }\end{array}$ \\
\hline 1969 & 10 & 92 \\
\hline 1970 & 5 & 72 \\
\hline
\end{tabular}

for the distribution of black phase Variable Oystercatchers in New Zealand, as adult oystercatchers have very few natural predators, especially in New Zealand, and predator selection for precursive chick plumages does not seem to occur (Baker, 1973).

Habitat selection has been shown to have a strong genetic component by Harris (1952) who found that individuals of forest and prairie subspecies of the Deermouse Peromyscus maniculatus that had been bred and raised in standard cages differed in their preference for various artificial habitats. The prairie-dwelling $P$. $m$. bairdi preferred habitats that resembled grasslands, and the forest-dwelling $P$. m. gracilis preferred habitats that resembled woodland. The conservative and specialized habitat selection shown by oystercatchers is strong evidence for an associated genetic component.

In the last decade, South Island Pied Oystercatchers have shown a partial change in habitat selection (Falla et al., 1966). Following heavy rain, and often coinciding with high water, flocks of South Island Pied Oystercatchers often leave marine littoral areas and forage in coastal fields for earthworms washed to the surface. Black phase Variable Oystercatchers have also been recorded in coastal fields in South Westland. A similar tendency to feed inland during winter has been described by Dare (1966) for European oystercatchers in the British Isles. He suggested that the transition from picking up surfacing worms to actively probing for them would be a short step, particularly for those birds which were already inland breeders, and any temporary shortage of normal shellfish foods would tend to accelerate the adoption and spread of this feeding habit. Heppleston (1971) showed that British populations of the Oystercatcher $(H . o$ occidentalis) in Scotland could not obtain enough food for their daily requirements from marine habitats in mid-winter, so they sought extra food from terrestrial habitats during high water. When snow covered coastal fields for prolonged periods he found many birds that had presumably died from starvation. 
The dichotomy of habitat selection shown by New Zealand oystercatchers would appear to be the result of a genetic component modified by habitat availability and interspecific competition. Habitat selection is a conservative factor in species formation since it reduces the probability that new isolates will be established beyond the present species border (Mayr, 1963). The limited speciation within the genus Haematopus is no doubt partly attributable to this restrictive selection.

\section{Niche Utilization}

New Zealand oystercatchers possess a wide range of prey-specific feeding behaviour patterns to cope with the various sizes and species of prey found under the widely-fluctuating environmental conditions of the sea shore. Each behaviour pattern is adapted to the structure and habits of the prey.

South Island Pied Oystercatchers have strongly-developed behaviour patterns for preying on bivalve molluscs. Gaping bivalves in shallow water are pierced between the valves with an initial sharp probe followed by repeated pressure thrusts into the centre of the prey until the adductor muscles are severed. The contents of the shell are then removed. Shellfish with their valves closed are hammered in the umbo region or at the edge of the gape with vertical jabs of the bill until access is gained to the flesh. Similar methods of preying on bivalves have been noted in European oystercatchers ( $H$. ostralegus) by Dewar (1908) and Tinbergen and Norton-Griffiths (1964). In regions where Variable Oystercatchers feed in estuaries they also prey extensively on bivalve molluscs, though they seem to do so only by piercing.

Variable Oystercatchers have distinctive behaviour patterns for taking relatively large prey items such as mussels and limpets from rocky shores. Gaping mussels (Mytilus edulis and Modiolus neozelanicus) are pierced between the valves and prised open in situ. Mussels with closed valves are hammered until an access hole is made through the shell. Small mussels may be removed from the substrate and orientated with their flatter ventral side uppermost for hammering. Dense concentrations of small Modiolus are dealt with simply by tearing shells from the substrate and swallowing them whole. Similar methods of preying on mussels were described by Norton-Griffiths (1967) for European oystercatchers. The only record of South Island Pied Oystercatchers feeding on mussels is that of Jackson (1964) who noted birds levering them open in Manakau Harbour.

The large shore limpet (Cellana denticulata) is a major prey item for $H$. unicolor. These gastropods are knocked off the rocks by sharp blows delivered with the bill or by levering between the foot of the limpet and the substrate with the bill held almost horizontal. The contents of the shell are removed by placing the upturned mollusc in a suitable crevice and paring the flesh from the shell with scissor-like movements of the bill. Chitons (Sypharochiton pelliserpentis and Amaurochiton glaucus) are dealt with in essentially the same manner. Similar behaviour was noted for European oystercatchers (Dewar, 1913) and North American Black Oystercatchers (Webster, 1941b). 
TABLE 3 The winter diet of mainland New Zealand oystercatchers in relation to habitat

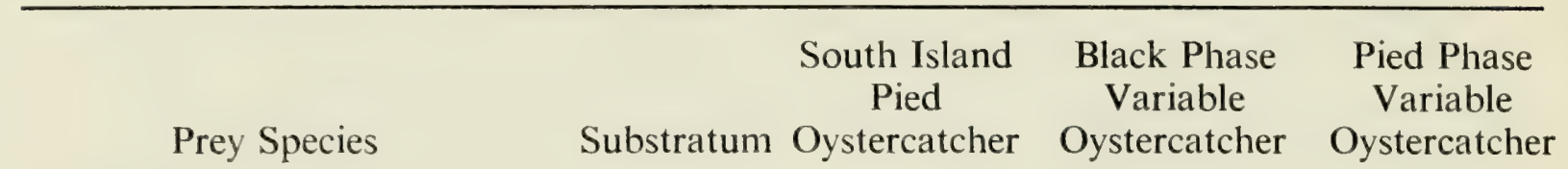

COELENTERATA: ACTINOZOA

Isactinia olivacea Rock

ANNELIDA: POLYCHAETA

Glycera americana

Nicon aestuariensis

Perinereis nuntia

Mud
Sand

$\mathrm{X}$

* : OllgochaETA

Allobophora caliginosa

Soil

$\mathrm{X}$
$\mathrm{X}$
$\mathrm{X}$

$\frac{x}{x}$

$\bar{x}$

MOLLUSCA: PELECYPODA

Amphidesma australe

A. subtriangulatum

Aulacomya maoriana

Chione stutchburyi

Dosinia anus

D. subrosea

Hydridella menziesi

Macomona liliana

Modiolus neozelanicus

Mytilus edulis

Perna canaliculus

Protothaca crassicosta

.

Mud \& sand $\quad \mathrm{X}$

Sand $\mathrm{X}$

Rock -

Mud \& sand X

Sand $\quad X$

" $\mathrm{X}$

Gravelly

sand \& mud $\mathrm{X}$

Mud X

Rock -

“

“

Sand

$\mathrm{X}$

$\mathrm{X}$

\section{: GASTROPODA}

Amphibola crenata

Cellana denticulata

C. flava

C. ornata

C. radians

Cominella glandiformis

Haliotis iris

Melagraphia aethiops

Zeacumantus subcarinatus

\section{: AMPHINEURA}

Amaurochiton glaucus

Sypharochiton pelliserpentis

CRUSTACEA : ISOPODA

Dynamanella huttoni

$$
\text { Rock }
$$

$\mathrm{X}$

$\begin{array}{ll}X & X \\ X & X \\ X & X \\ X & - \\ X & - \\ X & -\end{array}$

Mud

Rock

Rock

Mud \& rocks

Rock

“ X

Mud \& rocks $\quad \mathrm{X}$

X

$-$

X

$\mathrm{X}$

$\frac{x}{x}$

$x$

Rock

$\mathrm{X}$

\begin{tabular}{ll}
- & - \\
\hline$x$ & $X$ \\
$X$ & $X$ \\
$X$ & $X$ \\
$X$ & $X$
\end{tabular}

\section{: AMPHIPODA}

Talorchestia spp.

Sand

X

$\mathrm{X}$

\section{: DECAPODA}

Helice crassa

Mud

Hemigrapsis edwardsii

Palaemon affinis

Rock

$$
\frac{X}{X}
$$

$\mathrm{X}$ 


\begin{tabular}{|c|c|c|c|c|}
\hline Prey Species & Substratum & $\begin{array}{l}\text { South Island } \\
\text { Pied } \\
\text { Oystercatcher }\end{array}$ & $\begin{array}{l}\text { Black Phase } \\
\text { Variable } \\
\text { Oystercatcher }\end{array}$ & $\begin{array}{l}\text { Pied Phase } \\
\text { Variable } \\
\text { Oystercatcher }\end{array}$ \\
\hline *INSECTA: COLEOPTERA & & & & \\
\hline Costelytra zelandica (larvae) & Soil & $\mathrm{X}$ & - & - \\
\hline : LEPIDOPTERA & & & & \\
\hline Wiseana spp. (larvae) & Soil & $\mathrm{X}$ & - & - \\
\hline $\begin{array}{l}\text { PISCES: ACTINOPTERYGII } \\
\text { Rhombosolea plebeia }\end{array}$ & Sand & $X$ & - & - \\
\hline
\end{tabular}

Gastropods such as the mudsnail (Amphibola crenata) and the common topshell (Melagraphia aethiops) are taken with the same method described by Dewar (1910) for the purple shell (Purpura lapillus). The bill is inserted into the aperture and a hole is punched in the outside whorl of the shell opposite to the operculum. The shell is then rotated and the hole enlarged until the exposed soft-parts can be removed. Smaller gastropods such as the scavenging whelk (Cominella glandiformis) and the long-spined snail (Zeacumantus subcarinatus) are swallowed whole and the shells crushed in the stomach.

Although the three New Zealand species have similar prey-specific feeding behaviour patterns, their relative expression varies among the species. This difference is most obvious in heterogeneous habitats where the species overlap. At Kaikoura Peninsula extensive rock platforms are separated by occasional sandy beaches. Black, intermediate, and pied phase Variable Oystercatchers feed almost exclusively on the rocky areas whereas South Island Pied Oystercatchers generally take bivalves from the beaches. When the latter venture onto rocks they feed chiefly on chitons and small gastropods. Small limpets (Cellana radians) are only rarely eaten. Thus where the two mainland species coexist on rocky habitats the effects of competition are mitigated by differential niche utilization.

The combined effects of habitat selection and niche utilization are clearly revealed in comparing the winter diet of mainland New Zealand oystercatchers (see Table 3 ). Unfortunately, detailed studies on the diet of Chatham Islands Oystercatchers have not been made.

The separation of feeding niches described above is probably related to the relative sizes of the bills in the two species. Although they both have bills of similar length, South Island Pied Oystercatchers have a much slimmer and less robust bill (see Table 4), especially suited for probing in soft substrates for bivalves and polychaetes. The heavier bill and correspondingly more massive musculature associated with bill manipulation in Variable Oystercatchers are better suited to strenuous levering and hammering of large limpets from rocks.

The Chatham Islands Oystercatcher feeds mainly on chitons and small gastropods taken from rock surfaces. The bill of this bird, though considerably shorter than that of the mainland species, is slightly stouter than that of 
TABLE 4 Mean bill dimensions of New Zealand oystercatchers

\begin{tabular}{|c|c|c|c|c|}
\hline \multirow[b]{2}{*}{ Bill Dimension } & \multirow[b]{2}{*}{ Sex } & \multicolumn{3}{|c|}{ Mean \pm S.E. $(\mathrm{mm})$} \\
\hline & & $\begin{array}{l}\text { H. ostralegus finschi } \\
(\overbrace{}^{\top} \sigma^{\top}, \mathrm{N}=103 ; \\
\circ+\circ, \mathrm{N}=51)\end{array}$ & $\begin{array}{l}\text { H. unicolor } \\
\left(\sigma^{7} \sigma^{7}, \mathrm{~N}=50 ;\right. \\
\text { 우 }, \mathrm{N}=60)\end{array}$ & $\begin{array}{l}\text { H. chathamensis } \\
\left(\sigma^{7} \sigma^{7}, \mathrm{~N}=8 ;\right. \\
\circ \uparrow, \mathrm{N}=8)\end{array}$ \\
\hline Bill length & $\begin{array}{l}\mathrm{M} \\
\mathrm{F}\end{array}$ & $\begin{array}{l}80.9 \pm 0.35 \\
90.0 \pm 0.68\end{array}$ & $\begin{array}{l}84.4 \pm 0.77 \\
95.2 \pm 0.72\end{array}$ & $\begin{array}{l}67.8 \pm 0.97 \\
76.8 \pm 1.99\end{array}$ \\
\hline Bill height & $\begin{array}{c}\mathrm{M} \\
\mathrm{F}\end{array}$ & $\begin{array}{l}16.0 \pm 0.16 \\
16.0 \pm 0.12\end{array}$ & $\begin{array}{l}18.5 \pm 0.15 \\
18.9 \pm 0.19\end{array}$ & $\begin{array}{l}16.2 \pm 0.14 \\
16.9 \pm 0.23\end{array}$ \\
\hline Bill width & $\begin{array}{c}\mathrm{M} \\
\mathrm{F}\end{array}$ & $\begin{array}{l}13.1 \pm 0.41 \\
13.1 \pm 0.10\end{array}$ & $\begin{array}{l}15.5 \pm 0.13 \\
15.6 \pm 0.17\end{array}$ & $\begin{array}{l}13.1 \pm 0.09 \\
14.1 \pm 0.28\end{array}$ \\
\hline
\end{tabular}

the South Island Pied Oystercatcher (see Table 4), and seems better adapted for removing prey from rocks than for probing in sand or mud.

Although the three New Zealand species of oystercatcher are able to exploit invertebrate food supplies in most marine littoral habitats, their bills are best adapted to exploit different prey species. Where the mainland species overlap in homogeneous habitats, competition for food is minimized because of differential niche utilization.

\section{Food Requirements and Interspecific Competition}

It has been shown in a previous study (Baker, 1969) that the rate at which oystercatchers feed is extremely variable due to the modifying effect of several factors. Feedings rates vary with season, prey size, state of the tide, weather, and age of the birds. To reduce the influence of variation from these sources in my assessment, comparative food intake estimations were made for adult South Island Pied and Variable Oystercatchers at Jackson Bay in June, 1967. At this time a flock of 59 Variable and 14 South Island Pied birds were feeding together along an oceanic beach rich in tua-tuas (Amphidesma subtriangulatum ). Both species fed at approximately the same rate in this habitat (Fig. 3), and for similar periods during each tidal cycle. South Island Pied Oystercatchers ingested an average of $255.9 \mathrm{~g}$ dry weight of tua-tuas daily, or $51.8 \%$ of their body weight ( $\mathrm{N}=64$ observations). Variable Oystercatchers (data for colour phases combined) had an average daily food intake of $245.3 \mathrm{~g}$, which represented $35.8 \%$ of their body weight $(\mathrm{N}=$ 68 observations ).

Since Variable Oystercatchers are larger than South Island Pied Oystercatchers it might be expected that the latter would suffer proportionately greater heat losses. The metabolic rate of smaller animals is relatively greater than that of large ones because of the greater ratio of surface area (controlling heat loss) to body mass (controlling heat production). Until recently it was maintained that as the rate of heat production was controlled by the rate of heat loss, the metabolic rate was proportional to external surface area rather than to body weight. However, both Kleiber (1961) and Kendeigh (1970) 


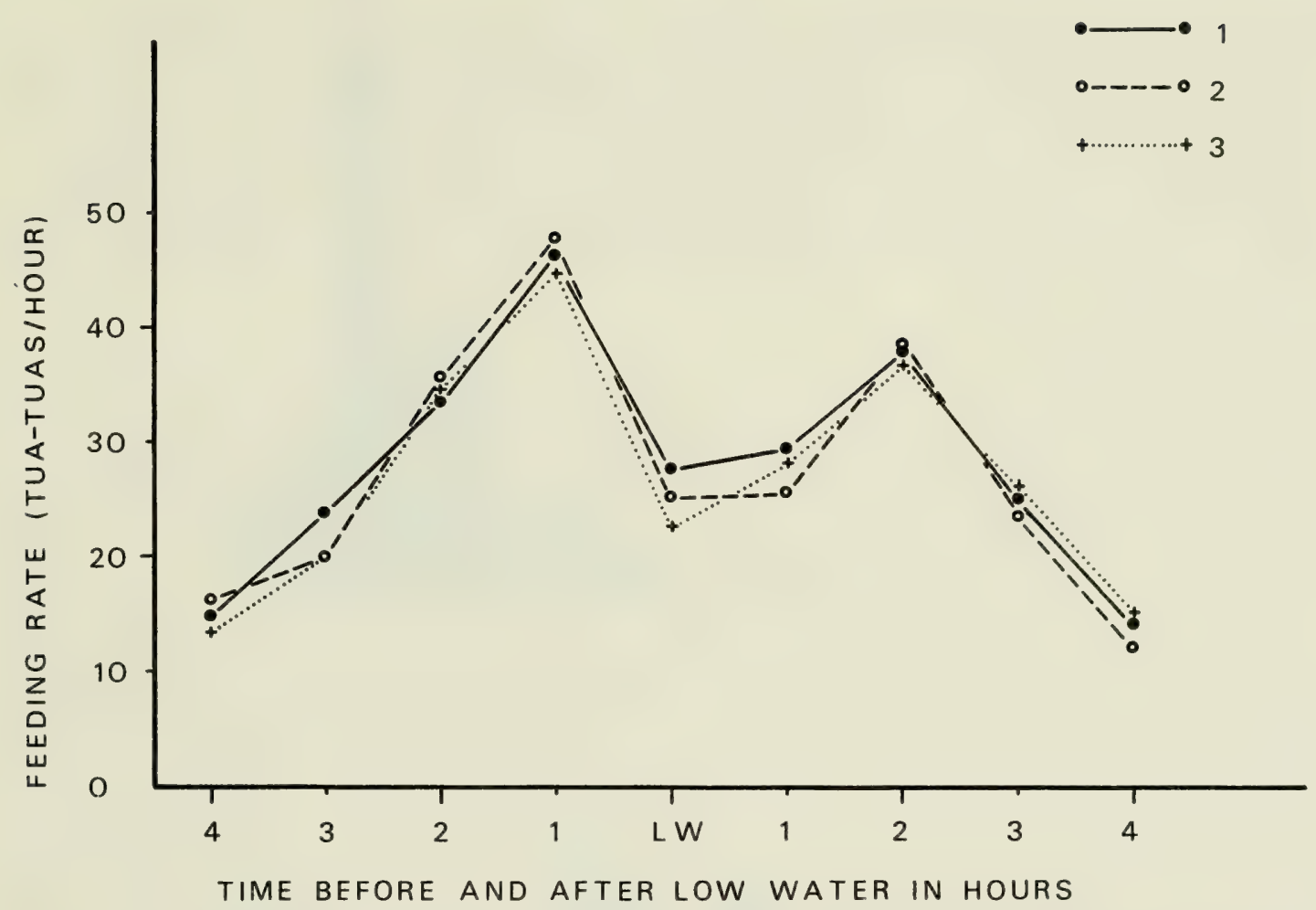

Fig. 3. Comparative feeding rates of mainland New Zealand oystercatchers at Jackson Bay. 1. Pied and intermediate phase H. unicolor; 2. H. ostralegus finschi; 3. Black phase $H$. unicolor.

demonstrated some factors other than external surface area that operate in determining heat loss. Thus Kendeigh (op. cit.) formulated an equation for calculating the existence energy (energy metabolized to maintain constant weight in captive conditions) directly from body weight in non-passerine species at $30^{\circ} \mathrm{C}$, as follows:

$$
\begin{aligned}
\mathrm{M} & =0.5404 \mathrm{~W}^{0.7545} \\
\text { or } \log \mathrm{M} & =-0.2673+0.7545 \log \mathrm{W} \\
\text { where } \mathrm{M} & =\text { existence metabolism in Kcal/Bird-day } \\
\text { and } \mathrm{W} & =\text { body weight in grams. }
\end{aligned}
$$

Taking the mean weights of South Island Pied and Variable Oystercatchers as $568 \mathrm{~g}$ and $692 \mathrm{~g}$ respectively (sexes combined, winter adults)

$$
\begin{aligned}
{ }^{\mathrm{M}} \text { S.I.P.O. } & =64.69 \mathrm{Kcal} / \text { Bird-day } \\
{ }^{\mathrm{M}} \text { Variable } & =75.09 \mathrm{Kcal} / \text { Bird-day }
\end{aligned}
$$

The larger Variable Oystercatcher therefore needs to ingest more food to maintain existence energy than does its smaller South Island congener. Since both species took similar amounts of food at Jackson Bay, it is apparent that $H$. unicolor is at a considerable competitive disadvantage to $H$. o. finschi in habitats with soft substrates, especially where food resources are limited.

When feeding on rocky substrates at Kaikoura Peninsula in July 1967, Variable Oystercatchers ate an average of $298.3 \mathrm{~g}$ dry weight of limpets per day, which was equivalent to $43.7 \%$ of their body weight ( $\mathrm{N}=46$ observations). Since the calorific values of limpets and tua-tuas are similar (4.330 and $4.304 \mathrm{Kcals} / \mathrm{g}$ respectively), Variable Oystercatchers feeding on 
limpets at Kaikoura ingested more food and energy per bird than they did when feeding on tua-tuas at Jackson Bay. This indicates that $H$. unicolor is much more efficient at utilizing foods on hard substrates than on soft ones, and points to the survival value of habitat selection and niche utilization, especially where competitive exclusion by large flocks of South Island Pied Oystercatchers occurs.

\section{Breeding Biology}

The breeding biologies of the New Zealand species of oystercatchers are essentially similar in their broader perspectives. Major differences relevant to systematics include time of breeding, dispersal to and from breeding areas, breeding dispersion, and egg weights and dimensions.

The two mainland species have different breeding seasons, although there is an overlap of approximately three months. South Island Pied Oystercatchers breed from August to December and Variable Oystercatchers from October to February (Fig. 4). Peaks in breeding activity are well separated, however, being September and December respectively. This asynchrony of breeding seasons is a major factor in ensuring the reproductive isolation of the two mainland species. Very little comparative data is available for the Chatham Islands Oystercatcher. Of ten clutches recorded on the Wildlife expedition in early summer 1970, eight were laid in October and two in early November. The peak in October is probably representative of the breeding activity of this species, suggesting that it most closely approaches the South Island Pied Oystercatcher in timing of the breeding season.

Both mainland species have different dispersal patterns from their winter feeding areas to breeding localities. South Island Pied Oystercatchers possess a well-developed migratory instinct, movement to breeding areas commencing in July and continuing to September. Distances as great as $1300 \mathrm{~km}$ (c. 800 miles ) are probably traversed by birds of northern populations moving south to breed. Variable and Chatham Islands Oystercatchers are nonmigratory. They either undertake local movements from wintering areas to breeding localities, or they retain isolated territories throughout the year.

Mainland New Zealand oystercatchers have mutually exclusive breeding dispersions (Fig. 5). Although the breeding ranges of the two mainland species overlap latitudinally in the South Island, allopatry is effected by separation of breeding habitats within these ranges. South Island Pied Oystercatchers breed inland on the shingle beds of snow-fed rivers, though since 1950 this species has spread increasingly onto arable land and high country tussock grasslands. Variable and Chatham Islands Oystercatchers are strictly coastal breeders, the former commonly breeding on small offshore islands.

Following the fledging of broods, South Island Pied Oystercatchers migrate back to their winter haunts. Movement begins in late December, reaches a peak in February and continues in northern New Zealand until April. Juveniles tend to migrate further north than adults, as northern flocks contain high proportions of birds of this age class. Resightings of colourbanded adults suggest that they usually return to the same wintering areas year after year, although some notable exceptions have been recorded. 


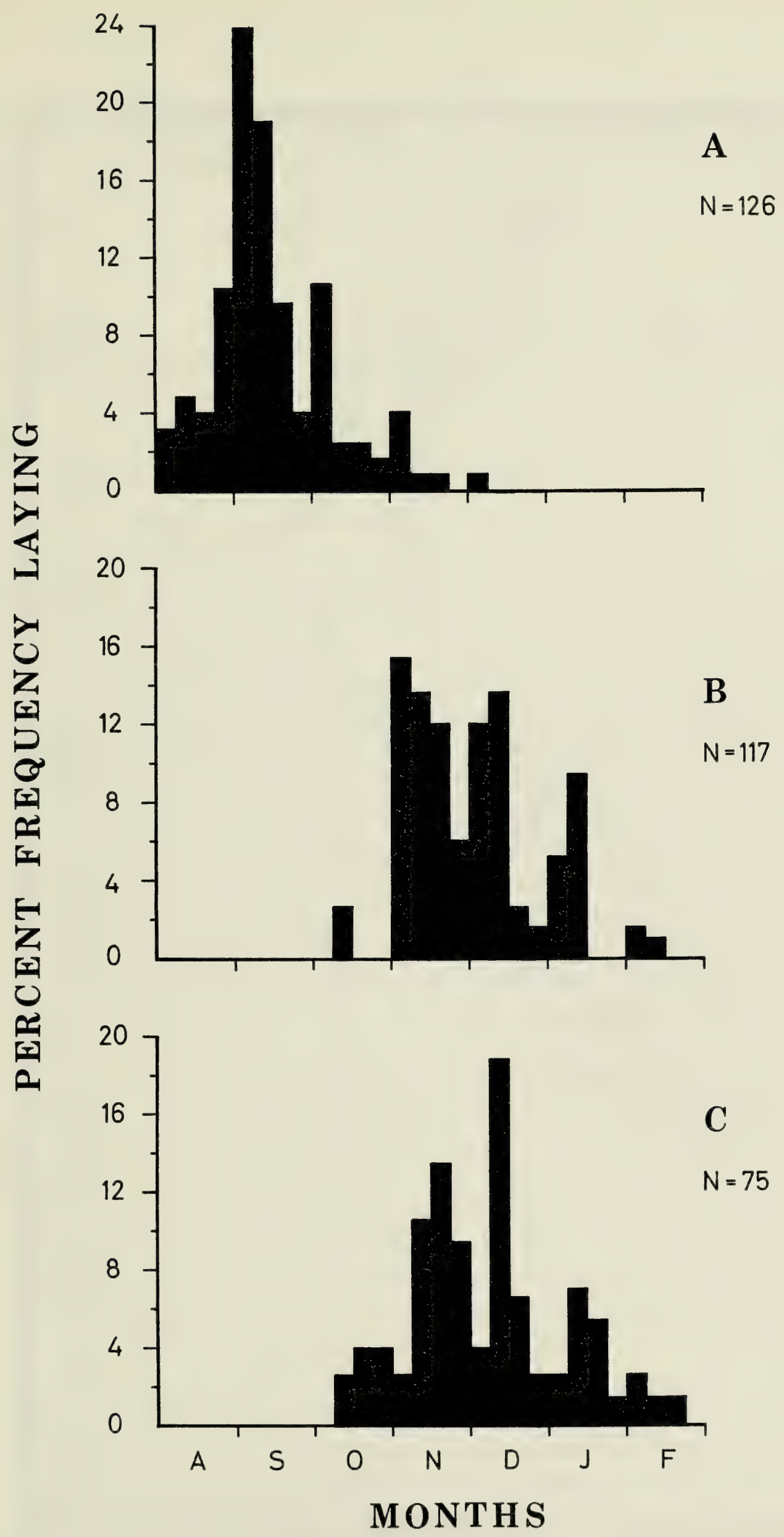

Fig. 4. Laying date histograms for the mainland New Zealand species of oystercatcher. The number of clutches analysed $(\mathrm{N})$ is shown for each histogram.

A. H. ostralegus finschi.

B. Black phase $H$. unicolor.

C. Pied and intermediate phase H. unicolor. 


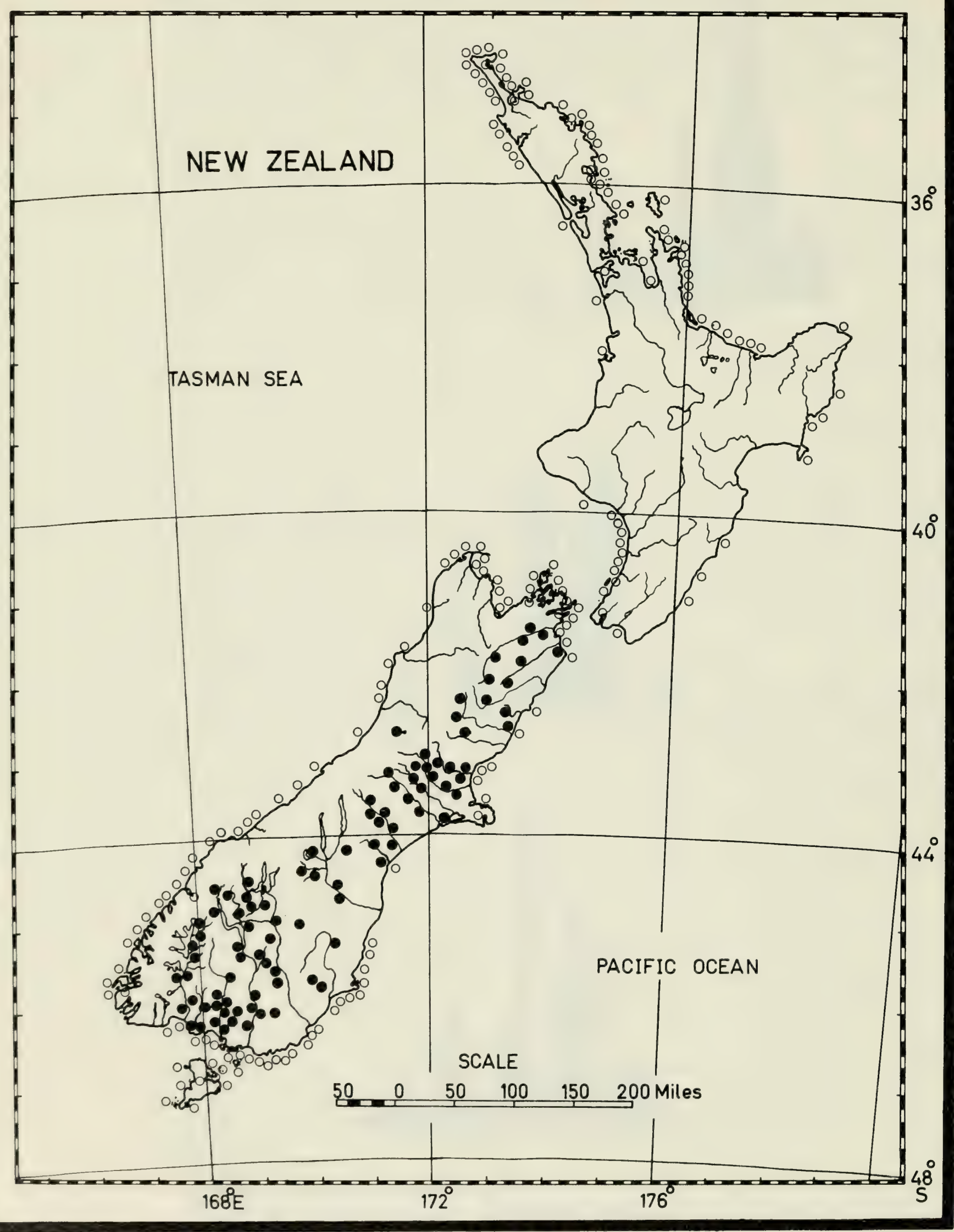

Fig. 5. Breeding dispersion of mainland New Zealand species of oystercatcher. Breeding records of $H$. unicolor (all colour phases lumped) are shown by open circles; those of $H$. ostralegus finschi are shown by black dots. 
TABLE 5 Dimensions and weights of eggs of New Zealand oystercatchers

Species $\quad N \frac{\text { Mean Dimensions }(\mathrm{mm})}{\text { Length } \pm \text { S.E. Width } \pm \text { S.E. }} \quad N \quad \frac{\text { Mean Weights }(\mathrm{g})}{\text { Weight } \pm \text { S.E. }}$

South Island

$\begin{array}{llllll}\text { Pied Oystercatcher } & 53 & 55.99 \pm 0.304 & 38.64 \pm 0.131 & 18 & 44.15 \pm 0.521\end{array}$

Variable

Oystercatcher

35

$58.76 \pm 0.377 \quad 40.93 \pm 0.165$

14

$49.36 \pm 0.492$

Chatham Islands

Oystercatcher

$21 \quad 56.94 \pm 0.481 \quad 40.50 \pm 0.260$

16

$45.96 \pm 0.442$

Variable and Chatham Islands Oystercatchers either stay in territories throughout the year or congregate in flocks at nearby feeding areas. Juveniles remain with their parents for several months, and then become independent. Banding returns indicate that Variable Oystercatchers wander most extensively in their second or third year of life before forming pair-bonds and localizing in an area. The greatest dispersal from natal sites of these immature birds so far recorded is $483 \mathrm{~km}$ (c. 300 miles), but the average for 27 colourmarked birds is only $36 \mathrm{~km}$ (c. 22 miles). Such local movements should be sufficient, however, to ensure adequate gene exchange between local populations and to account for the sporadic appearance of pied and intermediate phase birds in southern localities where only the black phase is known to breed.

Egg dimensions and weights for New Zealand oystercatchers are speciesspecific (Table 5). The eggs of South Island Pied Oystercatchers are smaller and lighter than those of Variable Oystercatchers (length, $\mathrm{t}=5.871 * * *$; width, $\mathrm{t}=10.893^{* * *}$; weight, $\mathrm{t}=7.105^{* * *}$ ). Chatham Islands Oystercatcher eggs are similar to those of the South Island Pied Oystercatcher in length but most closely resemble those of the Variable Oystercatcher in width, respective differences not being statistically significant. These dimensions account for the weight of eggs from the Chathams lying between those for the mainland species (Chatham vs S.I.P.O., $t=2.608^{*}$; Chatham vs Variable, $\mathrm{t}=5.138 * * *)$. Since most of the eggs used in this comparison were collected from similar latitudes, it seems probable that the differences are unbiased and reflect genetic differences between these species.

The broad similarity of the breeding biologies of New Zealand oyste :catchers outlined above is punctuated by significant species differences. Reproductive isolation of the two mainland species is assured by allopatric breeding dispersion and largely asynchronous breeding seasons. Chatham Islands Oystercatchers resemble South Island Pied Oystercatchers in time of breeding and in some egg parameters, whereas their coastal breeding and non-migratory habits indicate cladistic affinity with Variable Oystercatchers. 


\section{Parasites}

Parasites are of value to systematic studies of their hosts because they evolve together, and in some cases parasites are more conservative than their hosts (Mayr, 1969). Evidence provided by parasites must, however, be evaluated with caution, as they sometimes randomly shift hosts (Baer, 1957). Clay (1951, p. 207) has pointed out the limitations of applying the general principle that "the phylogenetic relationships of the Mallophaga reflect those of their hosts" to birds, as similarity of feather structure between unrelated birds can result in them having identical Mallophaga. However, she concluded that Mallophaga were often valuable as supporting evidence where the taxonomic status of a bird was in doubt.

Three genera and four species of Mallophaga occur on the feathers of New Zealand oystercatchers. The largest of these, Saemundssonia haematopi, is found on the head and upper neck of each species. Two body lice (Actornithophilus grandiceps and Quadraceps auratus) are common to all three oystercatchers, occurring on the feathers of the trunk and wings. A fourth species of Mallophaga (Quadraceps ridgwayi) is peculiar to the Variable Oystercatcher, occurring on all colour phases throughout their range. This louse is found on the feathers of the wings, the back, and on the scapulars. Hence the mainland species of oystercatcher can be distinguished on the presence or absence of $Q$. ridgwayi, and its absence from the Mallophaga fauna of the Chatham Islands Oystercatcher points to cladistic affinity of this bird with the South Island Pied Oystercatcher.

The internal helminth parasites of mainland New Zealand oystercatchers also show a dichotomy parallelling that of the Mallophaga, but to some extent this is due to different foods (and thus secondary hosts) taken by the species rather than species-specific differences. South Island Pied and Variable Oystercatchers have three genera of trematodes in common: Echinoparyphium sp. in the intestine, Notocotylus sp. in the caecae, and Cloacatrema sp. in the cloaca. They have different cestodes, however, as South Island Pied Oystercatchers host the small tapeworms Progynotaenia sp. and Hymenolepis sp., whereas Variable Oystercatchers have larger as yet unidentified species. Nematodes and an acanthocephalan have also been recorded from South Island Pied Oystercatchers, but they also are unidentified. Unfortunately, the helminth fauna of the Chatham Islands Oystercatcher is unknown.

More extensive sampling of Variable Oystercatchers is needed to describe its helminths adequately, but it does seem likely that, as with the Mallophaga, the New Zealand species of oystercatcher can be separated on differences in their helminth parasites. It seems equally likely that these differences reflect differences in the phylogeny of their hosts.

\section{Behaviour}

Since ethological differences between species in the breeding season may function as reproductive isolating mechanisms, the comparative breeding behaviour of species is important to systematic studies. The behaviour of the New Zealand species of oystercatcher is similar, although differences do occur in the various displays and vocalizations associated with breeding.

Pair formation in the mainland species of oystercatcher is usually effected 
TABLE 6 Occurrence of social piping displays by South Island Pied Oystercatchers at the Heathcote-Avon Estuary during 1967

\begin{tabular}{lccccccc}
\hline Month & May & June & July & Aug. & Sept. & Oct. & Nov. \\
$\begin{array}{l}\text { Mean no. of displays / } \\
1 \text { hr obs. period }\end{array}$ & 0 & 2 & 11 & 19 & 5 & 3 & 0 \\
\begin{tabular}{l}
$\%$ of total \\
\hline
\end{tabular} & 0 & 5 & 27.5 & 47.5 & 12.5 & 7.5 & 0 \\
\hline
\end{tabular}

while the birds are still in their winter flocks. Courtship leading to pair formation manifests itself primarily in vocalized piping displays (Fig. 6A). Such piping contains a dominant social element in contrast to aggressive piping which is agonistic in nature and frequently involves disputes over food and feeding sites (Fig. 6B). Social and aggressive piping also differ in that the former is mutually stimulating to several birds, groups of up to six birds being common in displays. Fighting among members of a group engaged in social piping is extremely rare, whereas it often follows aggressive piping. The sexual element in social piping of South Island Pied Oystercatchers is apparent because it is restricted to adult-plumaged birds (presumably sexually mature), and the frequency of these displays increases markedly with the onset of the breeding season (Table 6).

Ceremonial social piping parties of the European Oystercatcher $(H$. ostralegus) have received a great deal of attention from ornithologists (Selous, 1901; Huxley and Montague, 1925; Dirckson, 1932; Perry, 1938; Armstrong, 1947; Makkink, 1942). Two to a dozen birds were noted to participate, though three was the usual number, especially during the months of February, March, and April (= August, September, and October of the New Zealand breeding season). Social piping of the conspecific South Island Pied Oystercatcher seems similar in both form and timing to that of the European bird.

Social piping is similar in the three New Zealand species of oystercatcher. It involves specific posturing in which the participating birds move forward together, aligned side by side. Their tails are depressed, wings raised upwards and away from the body at the carpal flexure, necks extended forward and mandibles pointed downward (see Fig. 6A). The vocalizations associated with the piping display are characteristic of oystercatchers, beginning with sharp "pic" notes and gathering quickly into a prolonged chorus of highpitched calls "kervee-kervee-kervee-kervee" etc., finally ending in a short, lower trilling phrase. Sound spectrographs of the social piping vocalizations are similar in their general pattern (Fig. 7). Each spectrograph records piping vocalizations of two courting birds whose calls may or may not be in unison. Thus differences along the time axis are not likely to be significant, but are probably the result of the calls from the two birds being out of phase with one another. As the length of the piping call varies considerably even for the same pair of courting birds, differences in the length of the spectrographs are also not relevant.

The basic difference between the vocalizations of the species is that asso- 


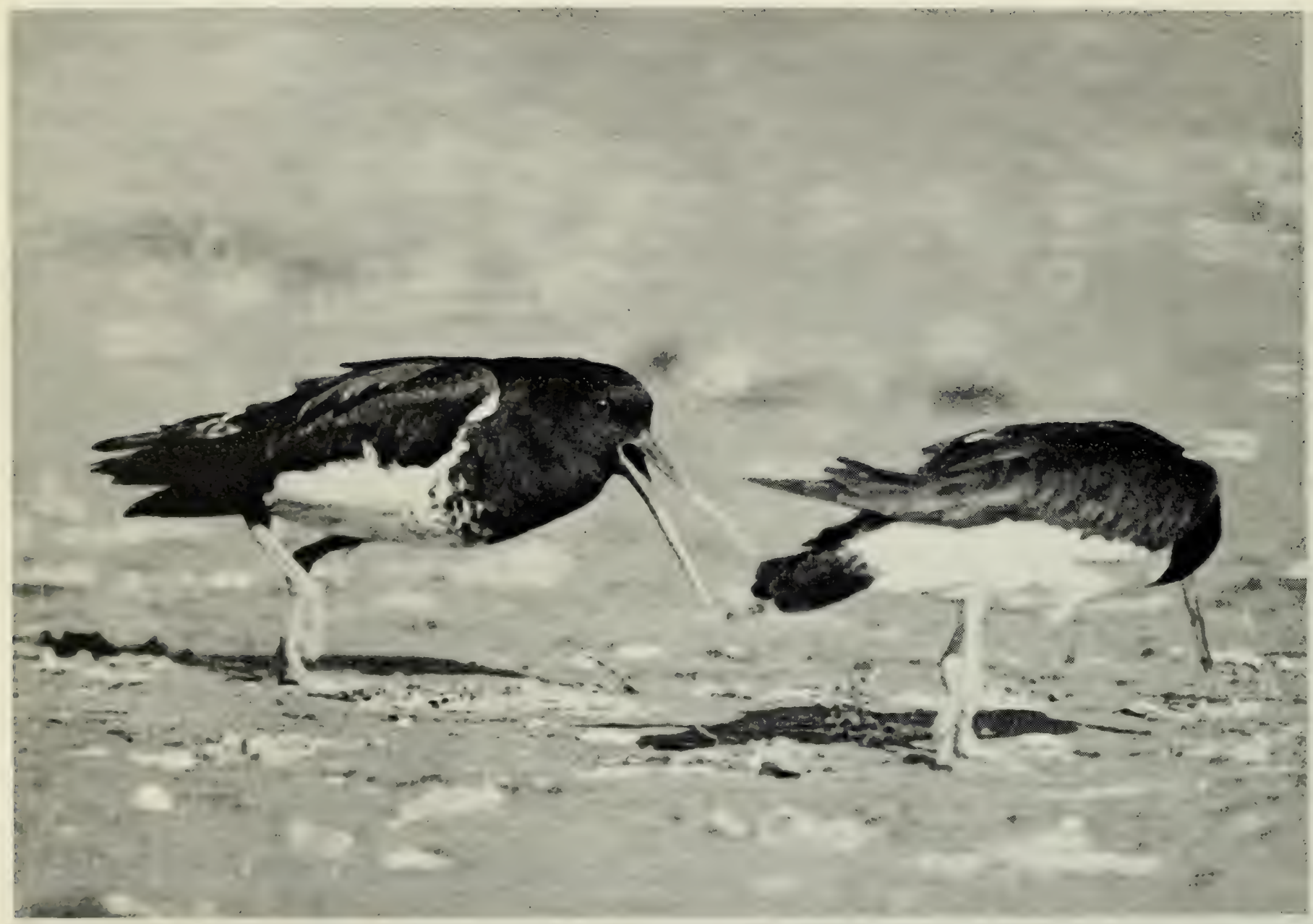

A

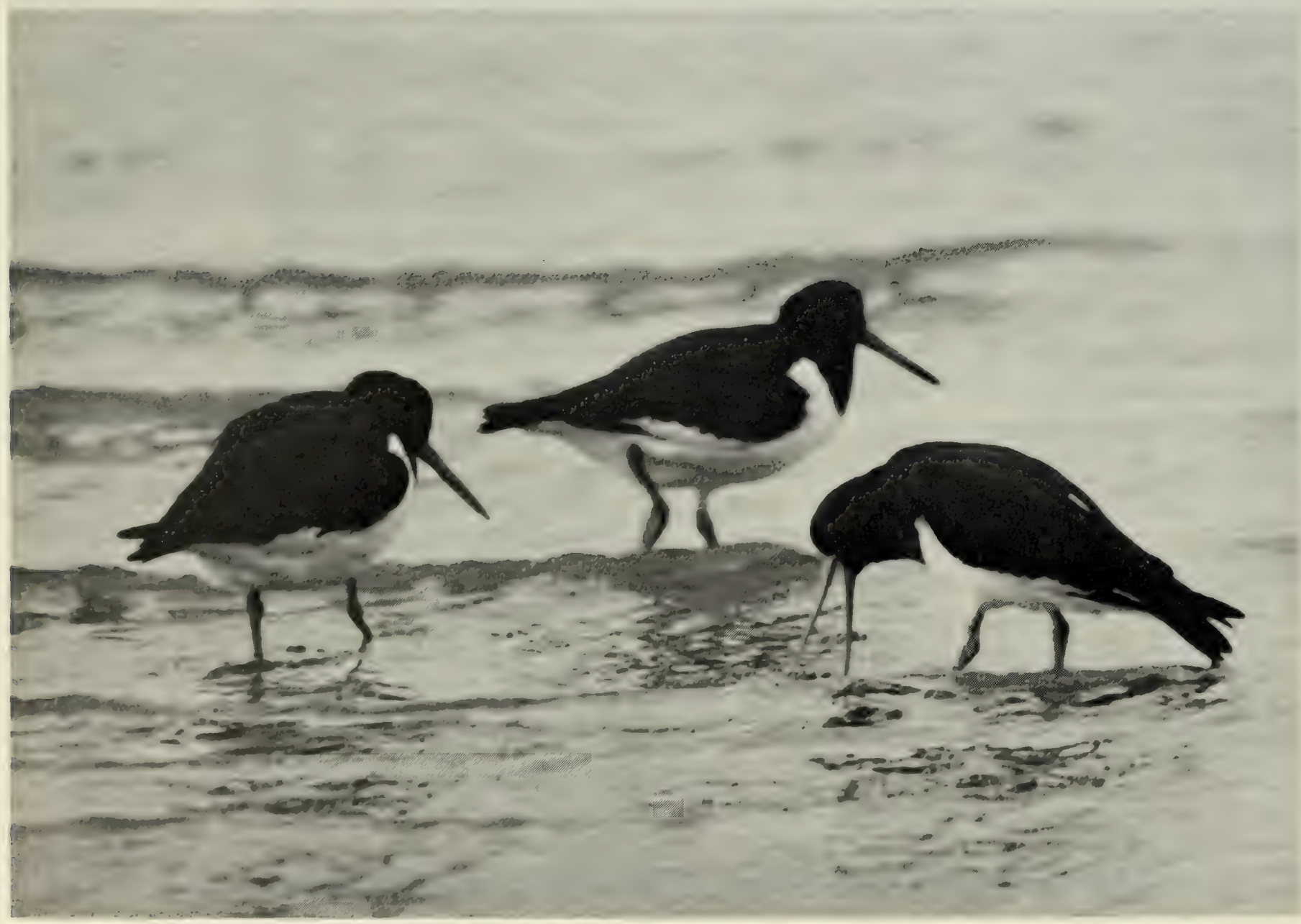

B 
ciated with pitch (and thus frequency). On each spectrograph a fundamental dominant frequency is depicted at approximately $2 \mathrm{KHz}$, above which is superimposed a first harmonic at approximately $4 \mathrm{KHz}$. The higher pitch of the calls of South Island Pied and Chatham Islands Oystercatchers discernable by ear is represented by a second harmonic on their spectrographs at about $7.5 \mathrm{KHz}$. The truncated tops of the "kervee" calls of these two species extend to approximately $15 \mathrm{KHz}$, far in excess of those of the Variable Oystercatcher (Fig. 8). Hence although the social piping vocalizations of the New Zealand species of oystercatcher are similar in structure, they do differ in their pitch. The vocalizations of the Chatham Islands and South Island Pied Oystercatchers are very similar in pitch and may indicate cladistic affinity of the two species.

Courtship behaviour of the South Island Pied Oystercatcher begins in June, reaches its greatest development in August, and ends in October. Similar social piping, involving identical posturing (Watt, 1955) reaches a peak in September for Variable Oystercatchers at Jackson Bay (D. Greaney, pers. comm.). The later seasonal development of social piping in this species is in accordance with its later breeding season.

Pair formation marks culmination of courtship behaviour and is indicated by copulation between members of a pair. Most pair formation of South Island Pied Oystercatchers is accomplished by mid-August, and seems to occur mainly at winter haunts. Before the inland migration of this species, it is common to see copulations at wintering areas, and pairs are often seen feeding and roosting together. Further evidence for pair formation at wintering localities is provided by observations of pairs sighted on migration in the MacKenzie Basin and on Canterbury riverbeds. Pair formation in European oystercatchers ( $H$. ostralegus) also seems to occur mainly within roosting flocks before territories are established (Harris, 1967).

In contrast to the foregoing, it also seems likely that at least some pairbonds are formed on arrival at the breeding grounds. Small flocks of up to 50 birds have occasionally been recorded migrating inland in the breeding season, and such flocks probably contain some unpaired birds. The differential migration and partial sexual segregation of South Island Pied Oystercatchers in winter suggested by the cyclical changes in the sex-ratio at the Heathcote-Avon Estuary (Baker, 1972), must mean that some pair-bonds were formed at the breeding grounds as this would be the only opportunity for potential mates to meet.

The formation of new pairs of Variable Oystercatchers is accomplished by September and precedes the establishment of territories. At Waipu Estuary in northern New Zealand, colour-banded birds retained their pair-bonds throughout 1970 , even though they roosted in a communal flock in winter. Pairs of Variable Oystercatchers on isolated stretches of coastline maintain

Fig. 6. Piping displays of New Zealand oystercatchers.

A. Social piping display of $H$. unicolor, during which the participating birds pipe in unison and frequently turn towards each other. B. Aggressive piping display of $H$. ostralegus finschi. Note the depressed tail. the wing raised upward and away from the body at the carpal flexure, the extended neck and the mandibles pointed downward. 


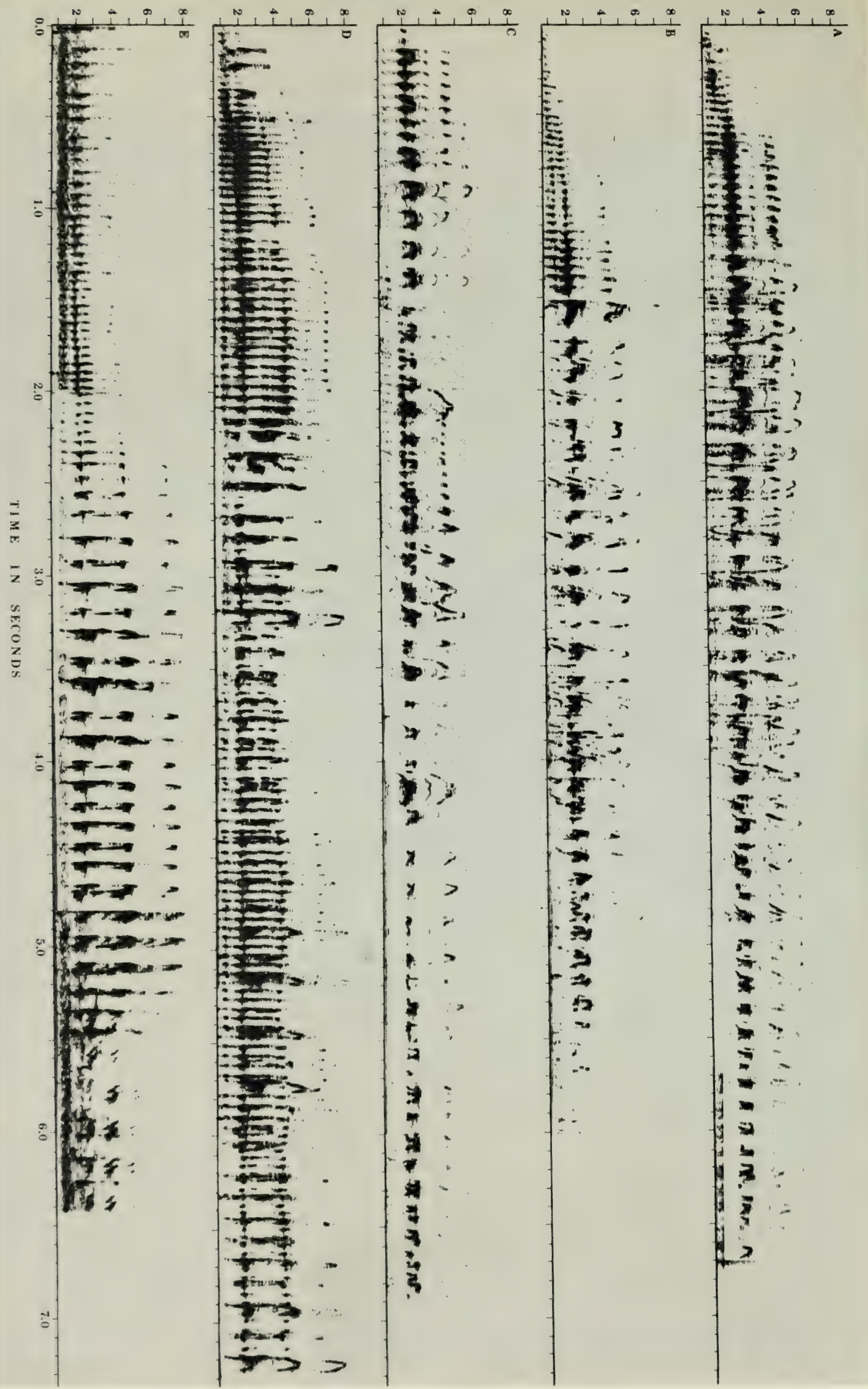

Fig. 7. Sound spectrographs of social piping vocalizations of New Zealand oystercatchers. Spectrographs were made at a tape speed of $71 / 2$ inches per second over the frequency range $80-8000 \mathrm{~Hz}$.
A. Pied phase $H$. unicolor.
B. Intermediate phase $H$. unicolor.
D. H. ostralegus finschi.
C. Black phase $H$. unicolor
E. H. chathamensis. 


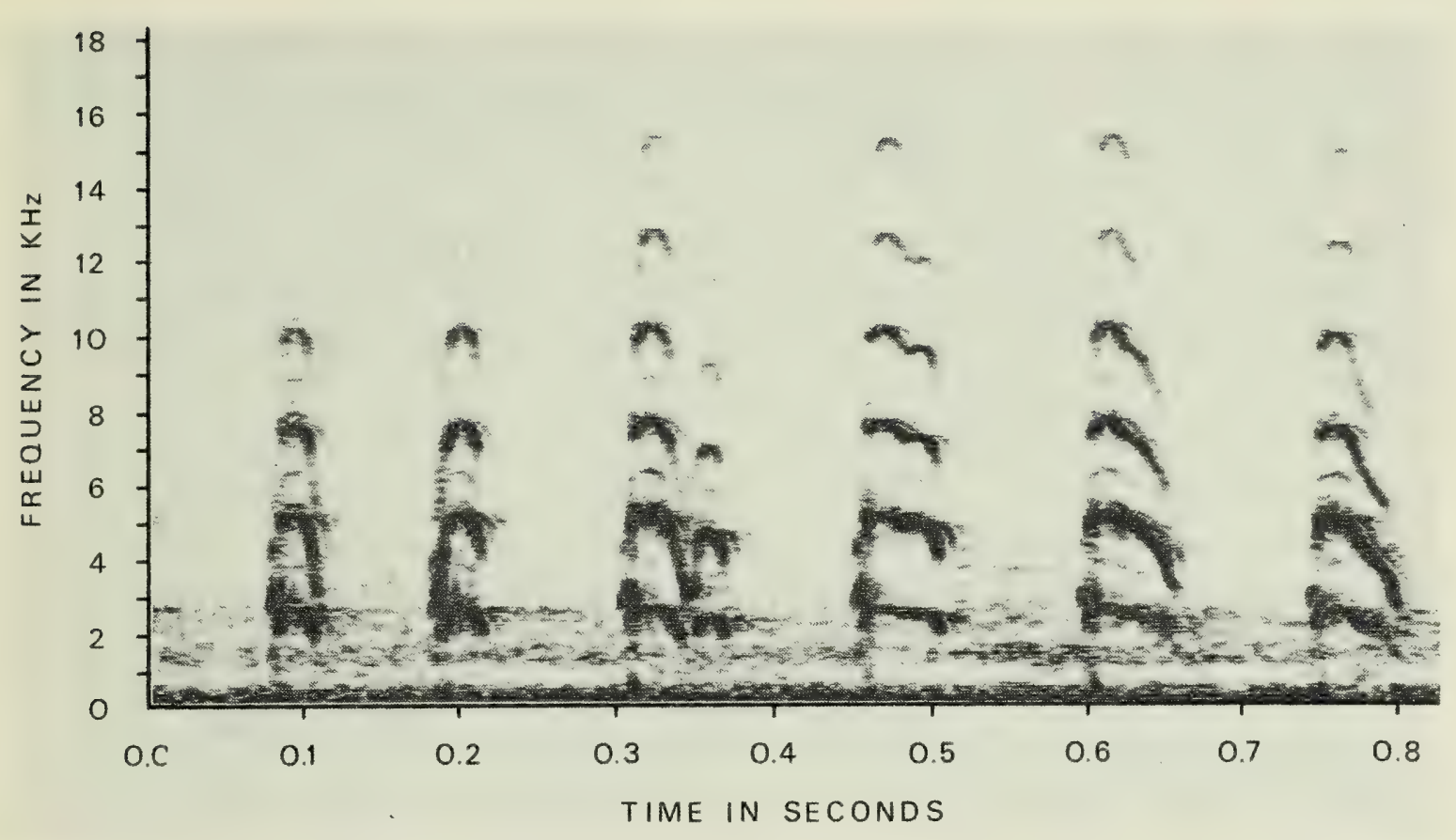

Fig. 8. Sound spectrograph of a segment of the social piping vocalization of a Chatham Islands Oystercatcher. This spectrograph was made from a segment of spectrograph $\mathrm{E}$ in Figure 8 (above the 5.0 second marker), at a tape speed of $71 / 2$ inches per second over a frequency range of $160-16,000 \mathrm{~Hz}$.

their pair-bonds throughout the year and drive off any intruding birds. The courtship behaviour and pair formation of the Chatham Islands Oystercatcher is unknown.

The copulatory behaviour of the three New Zealand species of oystercatcher is identical. Copulation is usually, but not always, preceded by specific posturing. The male posture involves a stealthy approach, with the head drawn between the shoulders and held to one side of the body. This hunchedup attitude is accentuated by a general lowering of the body, and by depressing and fanning the tail. Responsive females assume a passive posture, raising the body higher above the ground than is usual and at the same time erecting the tail feathers above the horizontal. The male mounts from behind and during coition maintains balance by flapping his wings. Occasionally, in all species, copulations occurred in which the male did not adopt the precopulatory posture, but either walked up to the female and mounted or flew onto her back from a short distance. Webster (1941a) noted that copulation of American Black Oystercatchers did not involve any special preliminary ceremony, the male commonly flying onto the female as described above.

The maintenance of pair-bonds throughout the year by Variable Oystercatchers is probably related to their copulatory behaviour. I have observed pairs copulating in the winter months of May, June and July, and since it is extremely unlikely that these copulations could have resulted in fertilization of ova (and may not have involved transference of seminal fluid), they probably served to strengthen the pair-bond between the participants. Such markedly aseasonal mating has not been recorded for South Island Pied Oystercatchers, and suggests perhaps that they do not always retain their pair-bonds throughout the year. However, South Island Pied Oystercatchers were seen copulating at the Heathcote-Avon Estuary at least five weeks 
before egg-laying. Huxley and Montague (1925, p. 894) noted the same behaviour in European oystercatchers and concluded that "the physiological capacity of the eggs to be fertilized was not synchronous with the psychological readiness for insemination". Applying this reasoning Makkink (1942) suggested that early copulations were part of the behavioural mechanism whereby pair-bonds were established and secured. Copulations occur at the breeding grounds up to the time of egg-laying, and it seems probable that these later acts bring about fertilization of the ova.

The behaviour associated with courtship and pair formation of New Zealand oystercatchers is similar for each species. Temporal separation in the formation of pair-bonds serves to reinforce reproductive isolation between the mainland species. Social piping, the display through which pairs are formed, is similar in structure for the three species, but the pitch of piping vocalizations is higher for South Island Pied and Chatham Islands Oystercatchers than it is for Variable Oystercatchers, suggesting cladistic affinity of the former two. However, it is unlikely that this difference could function as an ethological isolating mechanism between the two mainland species.

\section{Multivariate Assessment of Affinities}

In the previous sections, it has been shown that the Chatham Islands Oystercatcher has mixed affinities with the two mainland species, and thus it is difficult to decide whether $H$. chathamensis should be accorded species status or referred to a subspecies of unicolor or ostralegus. This is not an uncommon dilemma facing biologists attempting to group OTUs by eye on the basis of many characters, as noted by Schnell (1973).

Under these circumstances multivariate assessment of affinities is particularly appropriate as variation in multiple characters is considered simultaneously by such techniques, and an objective grouping is achieved. The results of multivariate analysis of coded data are presented below.

\section{CLUSTER ANALYSIS}

The relationships of the five OTUs, based on ecological and behavioural characters, are summarized in the Q-mode cluster analyses (Fig. 9). Both the correlation coefficient and taxonomic distance phenograms have high cophenetic correlations ( 0.939 and 0.987 respectively), indicating that they depict accurately the phenetic positions of the OTUs in 2-D space. The coefficient of correlation of cophenetic values is high $(0.931)$, showing that the two phenograms produce very similar results. In each phenogram the black, pied and intermediate colour phases of the Variable Oystercatcher emerge as a distinctive cluster. The divergence of the black phase from the other two phases is largely attributable to the increased use of rocky substrates by the black phase, as revealed by an inspection of the original input matrix. The South Island Pied and Chatham Islands Oystercatchers emerge as separate entities, and show little phenetic affinity with the Variable Oystercatcher. Thus the cluster analyses support the recognition of three species, as in the 1970 Annotated Checklist (OSNZ, 1970). 

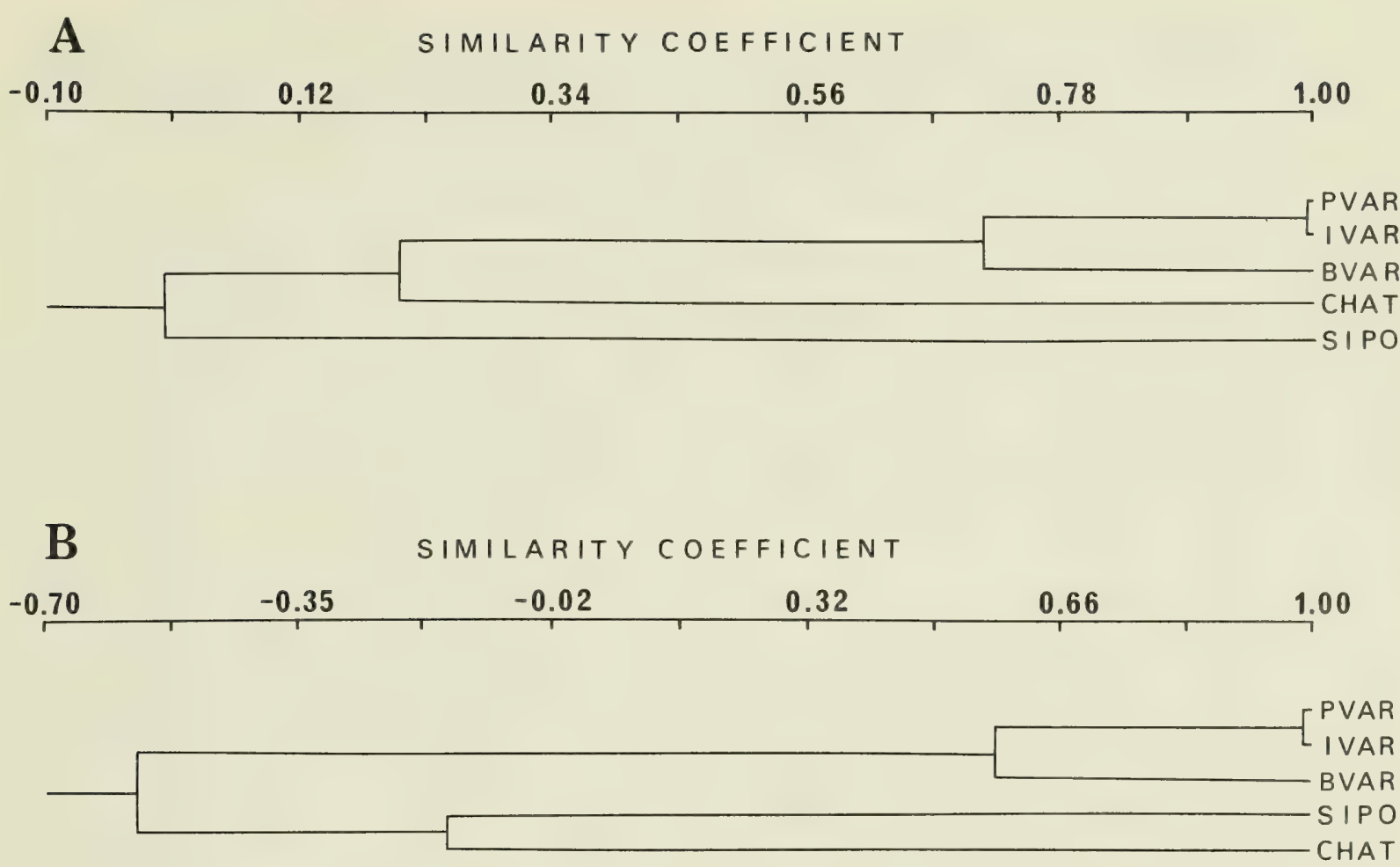

Fig. 9. Phenograms showing similarities among New Zealand oystercatchers, based on ecological and behavioural characters: PVAR, pied phase $H$. unicolor; IVAR, intermediate phase $H$. unicolor; BVAR, black phase $H$. unicolor; CHAT, $H$. chathamensis; SIPO, $H$. ostralegus finschi.

A. Phenogram from correlation coefficient.

B. Phenogram from taxonomic distance.

\section{PRINCIPAL COMPONENT ANALYSIS}

Ordination of the five OTUs in 3-D character space produced results similar to those obtained by cluster analysis (Fig. 10). A high proportion of the total character variance $(99.6 \%)$ was explained on the first three principal components $(59.2 \%$ on I, $33.0 \%$ on II and $7.4 \%$ on III), so the $3-\mathrm{D}$ plot is a reliable representation of phenetic relationships among the OTUs. The configuration again places the three colour phases of the Variable Oystercatcher in one cluster, and separates the South Island Pied Oystercatcher and the Chatham Islands Oystercatcher as outliers.

The relative importance of each character in determining the dispersion of OTUs in 3-D space is depicted by the loadings of the characters on the first three principal components (Table 7). Niche utilization characters of the Variable Oystercatcher (and the Chatham Islands Oystercatcher to a large degree) tend to have high positive loadings on component I, especially the characters: predominance of limpets and chitons in the diet, the occurrence of mussels as a significant dietary item, energy requirements, and maintenance of territories and pairbonds throughout the year. The latter two characters contribute substantially to niche utilization, because they result in pairs feeding in set areas on known and relatively abundant supplies of food. Most of the high negative loadings involve niche characteristics of the South Island Pied Oystercatcher, so component I can be thought of in this analysis as a "niche utilization" factor. The pattern of loadings on component II is much harder to generalize, but it contains high positive loadings of most characters that do not load heavily on component I. Adaptive superiority 
TABLE 7 Loadings of characters on the first three principal components based on a matrix of correlations among ecological and behavioural characters

\begin{tabular}{rlccc}
\hline \multicolumn{2}{c}{ Character No. } & & & \\
and Abbreviation & Component I & Component II & Component III \\
1 & ROCK & 0.495 & -0.324 & -0.806 \\
2 & SAND & 0.301 & 0.506 & 0.808 \\
3 & ESTY & -0.975 & -0.223 & -0.002 \\
4 & ESBI & -0.975 & -0.224 & -0.002 \\
5 & LIMP & 0.975 & 0.224 & 0.002 \\
6 & MUSS & 0.970 & 0.228 & 0.002 \\
7 & ADAP & -0.458 & 0.880 & 0.125 \\
8 & ENER & 0.975 & 0.223 & 0.002 \\
9 & PBIL & 0.029 & 0.992 & 0.125 \\
10 & LBIL & 0.030 & 0.994 & 0.125 \\
11 & SBIL & 0.030 & 0.990 & 0.126 \\
12 & EARL & -0.422 & -0.901 & -0.103 \\
13 & WEIT & -0.422 & -0.900 & -0.105 \\
14 & OVAT & -0.975 & -0.223 & -0.002 \\
15 & LENG & 0.422 & 0.901 & 0.103 \\
16 & MIGR & -0.975 & -0.223 & -0.002 \\
17 & TERR & 0.975 & 0.223 & 0.002 \\
18 & PAIR & 0.975 & 0.223 & 0.002 \\
19 & QRID & 0.422 & 0.901 & 0.103 \\
20 & PROG & -0.906 & 0.416 & 0.078 \\
21 & HYME & -0.906 & 0.416 & 0.078 \\
22 & VOCA & -0.422 & -0.901 & -0.103 \\
23 & ACOP & 0.030 & 0.992 & 0.125 \\
\hline
\end{tabular}

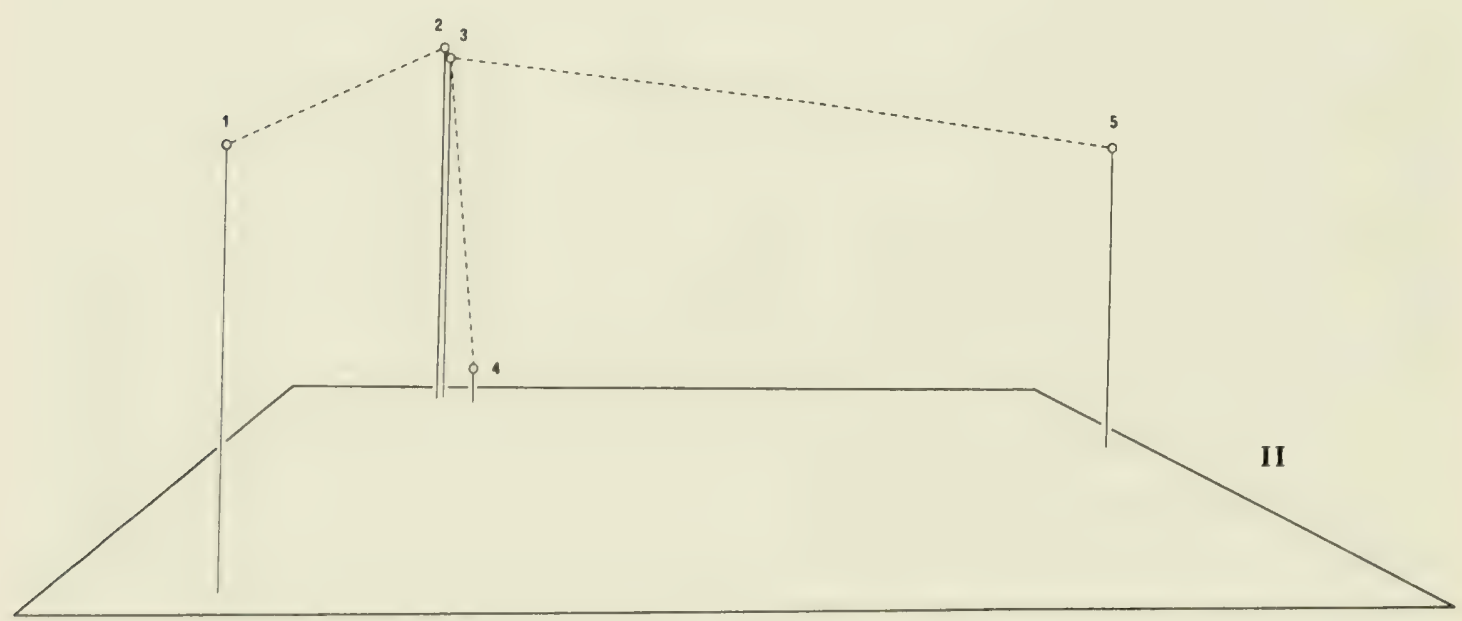

Fig. 10. Projections of OTUs on the first three principal components, based on a matrix of correlations among ecological and behavioural characters: $1, H$. ostralegus finschi; 2 , intermediate phase $\boldsymbol{H}$. unicolor; 3 , pied phase $\boldsymbol{H}$. unicolor; 4 , black phase $H$. unicolor; $5, \boldsymbol{H}$. chathamensis. 
on rocky habitats, bill characters, egg width, presence of $Q$. ridgwayi and aseasonal copulation all have high positive loadings on component II, whereas early breeding, egg weight, migratory habit and vocalization have high negative loadings. As in component I, the positive loadings tend to represent attributes of the Variable Oystercatcher, and separate it from the South Island Pied Oystercatcher whose attributes are represented by the negative loadings. Component II therefore seems to represent a general composite factor of diverse ecological and behavioural characters. Only habitat selection loads highly on component III, with predominant use of sandy habitats loading positively and predominant use of rocky habitats loading negatively.

\section{NONMETRIC MULTIDIMENSIONAL SCALING}

This ordination technique produces results similar to principal components analysis (Fig. 11). It is noticeable that the three colour phases of the Variable Oystercatcher cluster more tightly than they do in the principal component projections, and that the South Island Pied and Chatham Islands Oystercatchers separate from this central cluster as more distant outliers. This compression of the shorter distances and lengthening of larger distances in nonmetric scaling relative to principal components analysis has been also noted by Rohlf (1970, 1972), who suggested that the nonmetric scaling solution is to be preferred unless a large number of OTUs is involved. His recommendation was based on the premise that nonmetric scaling gives a better fit of the data to a k-dimensional configuration, based on the correlation of the distances between them. For the present analysis, the fit of the 3-D configuration to the data was almost perfect, the value for stress being very low $(0.001)$. Though there is little to choose between the results of the ordination techniques used in this study (largely because they both achieve an unusually high degree of fit to the data), the nonmetric multidimensional scaling projections seem preferable as they effectively sharpen the boundaries between distinct clusters.

In summary, the cluster analyses and the ordination techniques order the five OTUs into three groups which are sufficiently distinctive to warrant species status. Although principal components analysis and nonmetric scaling give similar results the latter seems preferable for methodological reasons. The interpretation of component I as a "niche utilization" factor which accounts for almost $60 \%$ of the total variance in the character matrix suggests that differential niche utilization may have been of prime importance in the speciation of New Zealand oystercatchers.

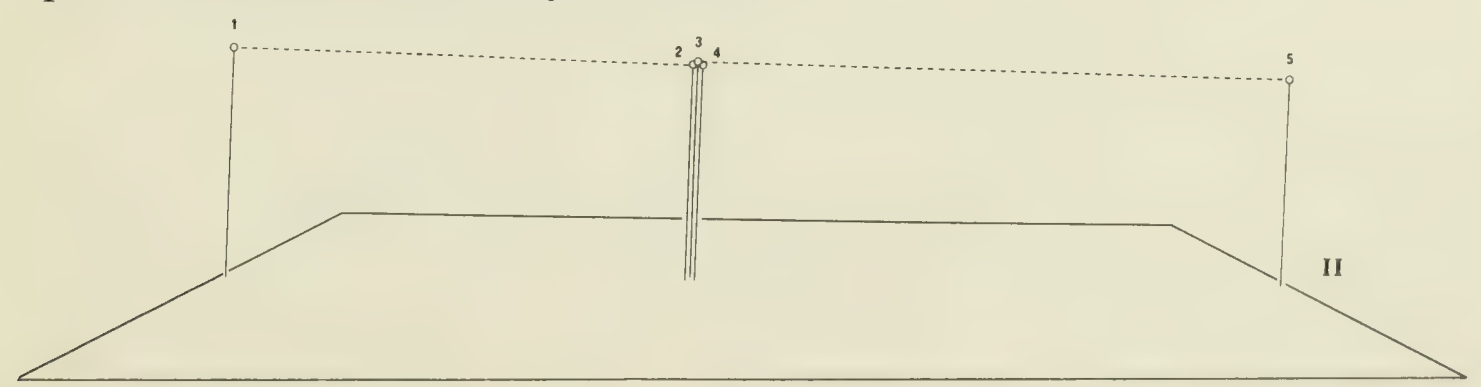

I

Fig. 11. Projections of OTUs on the first three dimensions of a nonmetric multidimensional scaling analysis. The OTUs are identified by numbers as in Figure 10. 


\section{Systematic Conclusions}

As reproductive isolation of the South Island Pied Oystercatcher and the Variable Oystercatcher is assured by their allopatry and asynchonous breeding seasons, they obviously represent good species. The Chatham Islands Oystercatcher shows a curious mixture of phenetic affinities with the two mainland species. It resembles the South Island Pied Oystercatcher in breeding phenology, social piping vocalizations, and egg size, and both lack the louse Quadraceps ridgwayi which is found on the Variable Oystercatcher. It resembles the Variable Oystercatcher in its predominantly rock-dwelling ecology, coastal breeding and sedentary habits. Simultaneous assessment of these affinities by multivariate techniques orders the OTUs into three distinct clusters, and suggests that three species should be recognized. It therefore seems prudent, on the basis of ecological and behavioural evidence, to refer chathamensis to separate species status, and accept the classification proposed in the Annotated Checklist of New Zealand birds (OSNZ, 1970) as follows:

1) South Island Pied Oystercatcher-Haematopus ostralegus finschi Martens, 1897.

2) Variable Oystercatcher - Haematopus unicolor Forster, 1844.

3) Chatham Islands Oystercatcher - Haematopus chathamensis Hartert, 1927. 


\section{Acknowledgments}

This study was carried out during tenure of the Wildlife Scholarship in the Department of Zoology, University of Canterbury, New Zealand. I would particularly like to thank Professor G. A. Knox, Dr. J. Warham, and Dr. R. S. Bigelow for advice, encouragement and criticism throughout the study. Mallophaga were kindly identified by Professor R. L. C. Pilgrim, and helminths by Mrs. F. R. Allison. I am grateful to Dr. G. R. Williams, B. D. Bell and D. V. Merton of the Wildlife Department of Internal Affairs for including me in the 1970 Chatham Island expedition. Dr. J. C. Barlow and Dr. C. McGowan read the manuscript and made helpful suggestions for improvement. Three-dimensional calcomp plots were provided through the courtesy of Ralph Gibson. For field assistance I thank Dr. J. D. Coleman, K. Horgan, Dr. J. A. Mills, L. McPherson, Dr. Abdul Moeed, H. Best and my wife Sue, who also drafted the figures. Nest record cards of the Ornithological Society of New Zealand were supplied through the courtesy of Mr. D. E. Crockett, and information in the recording scheme was generously supplied by Mr. A. T. Edgar. Mrs. Maria Thinh typed the manuscript, and I would like to thank her for her extreme diligence and industry. Finally, I would like to thank the staff of the ROM Department of Photography and the Library for their assistance in the preparation of this report. 


\section{Literature Cited}

ARMSTRONG, E. A.

1947 Bird display and behaviour; an introduction to the study of bird psychology. London, Lindsay Drummond. 430 pp.

BAER, J. G., ed.

1957 First symposium on host specificity among parasites of vertebrates. Zool. Inst. Univ. Neuchatel. 324 pp.

BAKER, A. J.

1969 The comparative biology of New Zealand oystercatchers. M.Sc. thesis, University of Canterbury. 222 pp.

1972 Systematics and affinities of New Zealand oystercatchers. Ph.D. thesis, University of Canterbury. 134 pp.

1973 Distribution and numbers of New Zealand oystercatchers. Notornis, vol. 20 , no. 2 , pp. 128-144.

BANCROFT, G.

1927 Breeding birds of Scammons Lagoon, Lower California. Condor, vol. 29 , no. 1 , pp. 29-57.

BONHAM-CARTER, G. F.

1967 Fortran IV program for Q-mode cluster analysis of non-quantitative data using IBM 7090/7094 computers. University of Kansas Geological Survey Computer Contribution, no. 17. Lawrence, University of Kansas, Geological Survey. 28 pp.

CLAY, T.

1951 The Mallophaga as an aid to the classification of birds with special reference to the structure of feathers. In Hörstadius, S., ed. Proceedings of the 10th International Ornithological Congress. Uppsala, Almquist and Wiksell, pp. 207-215.

CROVELLO, T. J.

1969 Effects of change of characters and of numbers of characters in numerical taxonomy. Am. Midl. Nat., vol. 81, no. 1, pp. 68-86.

DARE, P. J.

1966 The breeding and wintering populations of the Oystercatcher (Haematopus ostralegus Linnaeus) in the British Isles. Fishery Invest., Lond., ser. 2, vol. 25, no. 5, pp. 1-69.

DELACOUR, J. AND E. MAYR

1945 The family Anatidae. Wilson Bull., vol. 57, no. 1, pp. 3-55.

DEWAR, J. M.

1908 Notes on the Oystercatcher (Haematopus ostralegus) with reference to its habit of feeding upon the mussel (Mytilus edulis). Zoologist, ser. 4, vol. 12, no. 804, pp. 201-212.

1910 A preliminary note on the manner in which the Oystercatcher (Haematopus ostralegus) attacks the purple-shell (Purpura lapillus). Zoologist, ser. 4, vol. 14, no. 825, pp. 109-112.

1913 Further observations on the feeding habits of the Oystercatcher (Haematopus ostralegus). Zoologist, ser. 4, vol. 17, no. 860, pp 41-56.

I)IRCKSEN, R.

1932 Die Biologie des Austernfischers, der Brandseeschwalbe und der Küstenseewalbe nach Beobachtungen und Untersuchungen auf Norderoog, J. Orn., jahrgang 80, heft 4, pp. 427-521.

FALLA, R. A., R. B. SIBSON AND E. G. TURBOTT

1966 A field guide to the birds of New Zealand and outlying islands. London, Collins. 254 pp.

FARRIS, J.S.

1969 On the cophenetic correlation coefficient. Syst. Zool., vol. 18, no. 3, pp. 279-285. 
FICKEN, R. W. AND M. S. FICKEN

1966 A review of some aspects of avian field ethology. Auk, vol. 83, no. 4, pp. 637-661.

FLEMING, C. A.

1939 Birds of the Chatham Islands. Pt. II. Emu, vol. 38, pp. 494-495.

1962 New Zealand biogeography; a paleontologist's approach. Tuatara, vol. 10 , pt. 2, pp. 53-108.

HARRIS, M. P.

1967 The biology of Oystercatchers Haematopus ostralegus on Skokholm Island, S. Wales. Ibis, vol. 109, no. 2, pp. 180-193.

HARRIS, V. T.

1952 An experimental study of habitat selection by prairie and forest races of the deermouse (Peromyscus maniculatus). Contr. Lab. Vertebr. Biol., Univ. Mich., no. 56, pp. 1-53.

HARTLEY, P. H. T.

1948 The assessment of the food of birds. Ibis, vol. 90, no. 3, pp. 361-381. HEPPLESTON, P. B.

1971 The feeding ecology of Oystercatchers (Haematopus ostralegus L.) in winter in northern Scotland. J. Anim. Ecol., vol. 40, no. 3, pp. 651-672.

HINDE, R. A.

1970 Animal behaviour - a synthesis of ecology and comparative psychology. 2nd ed. New York, McGraw-Hill. 876 pp.

HOLLOWAY, J. D. AND N. JARDINE

1968 Two approaches to zoogeography: a study based on the distributions of butterflies, birds and bats in the Indo-Australian area. Proc. Linn. Soc. Lond., vol. 179, no. 2, pp. 153-188.

HUXLEY, J. S. AND F. A. MONTAGUE

1925 Studies on the courtship and sexual life of birds V. The Oyster-catcher (Haematopus ostralegus L.). Ibis, ser. 12, vol. 1, no. 4, pp. 868-897.

JACKSON, R. W.

1964 Notes on South Island Pied Oystercatchers. In New Zealand Recording Scheme, Ornithological Society of New Zealand. p. 4. Mimeographed.

JOHNSGARD, P. A.

1965 Handbook of waterfowl behaviour. Ithaca, Cornell University Press, Comstock Publishing Associates. 378 pp.

KENDEIGH, S. C.

1970 Energy requirements for existence in relation to size of bird. Condor, vol. 72 , no. 1 , pp. 60-65.

KLEIBER, $M$.

1961 The fire of life, an introduction to animal energetics. New York, Wiley. 454 pp.

KRUSKAL, J. B.

1964 Multidimensional scaling by optimizing goodness of fit to a nonmetric hypothesis. Psychometrika, vol. 29, no. 1, pp. 1-27.

MAKKINK, G. F.

1942 Contribution to the knowledge of the behaviour of the OysterCatcher (Haematopus ostralegus L.). Ardea, jaargang 31, aflevering $1 / 2$, pp. 23-74.

MAYR, E.

1963 Animal species and evolution. Cambridge, Harvard University Press, Belknap Press. 797 pp.

1969 Principles of systematic zoology. New York, McGraw-Hill, 428 pp.

MAYR, E., E. G. LINSLEY AND R. L. USINGER

1953 Methods and principles of systematic zoology. New York, McGrawHill. 328 pp. 
MOYNIHAN, M.

1958 A revision of the family Laridae (Aves). Am. Mus. Novit., no. 1928, pp. $1-42$.

NORTON-GRIFFITHS, M.

1967 Some ecological aspects of the feeding behaviour of the Oystercatcher (Haematopus ostralegus) on the edible mussel (Mytilus edulis ). Ibis, vol. 109, no. 3, pp. 412-424.

ORNITHOLOGICAL SOCIETY OF NEW ZEALAND

1953 Checklist of New Zealand birds. Wellington, A. H. \& A. W. Reed for the Ornithological Society of New Zealand. 80 pp.

1970 Annotated checklist of the birds of New Zealand including the birds of the Ross dependency. Wellington, A. H. \& A. W. Reed for the Ornithological Society of New Zealand. 96 pp.

PERRY, R.

1938 At the turn of the tide; a book of wild birds. London, Lindsay Drummond. $206 \mathrm{pp}$.

ROHLF, F. J.

1970 Adaptive hierarchial clustering schemes. Syst. Zool., vol. 19, no. 1, pp. 58-82.

1972 An empirical comparison of three ordination techniques in numerical taxonomy. Syst. Zool., vol. 21, no. 3, pp. 271-280.

SCHNELL, G. D.

1973 A reanalysis of nest structure in the weavers (Ploceinae) using numerical taxonomic techniques. Ibis, vol. 115, no. 1, pp. 93-106.

SELANDER, R. $\mathrm{K}$.

1969 The ecological aspects of the systematics of animals. In Systematic biology. Proceedings of an international conference conducted at the University of Michigan, Ann Arbor, Michigan, June 14-16, 1967, sponsored by the National Research Council. National Academy of Sciences Publicition, no. 1692. Washington, D.C., National Academy of Sciences, pp. 213-239.

1971 Systematics and speciation in birds. In Farner, D. S. and J. R. King. Avian Biology. Vol. 1. New York, Academic Press, pp. 57-147.

SELOUS, E.

1901 Bird watching. London, J. M. Dent. 347 pp.

SMITH, N. G.

1966 Evolution of some Arctic gulls (Larus): an experimental study of isolating mechanisms. Ornithological Monographs 4. The American Ornithologists' Union. 97 pp.

SOKAL. R. R. AND F. J. ROHLF

1962 The comparison of dendrograms by objective methods. Taxon, vol. 11 , no. 1 , pp. 33-44.

SOKAL, R. R. AND P. H. A. SNEATH

1963 Principles of numerical taxonomy. San Francisco, Freeman. 359 pp.

TINBERGEN, N. AND M. NORTON-GRIFFITHS

1964 Oystercatchers and mussels. Br. Birds, vol. 57, no. 2, pp. 64-70.

TRAVERS, H. H. AND W. T. L. TRAVERS

1872 On the birds of the Chatham Islands, with introductory remarks on the avifauna and flora of the island in relation to those of New Zealand. Trans. Proc. N.Z. Inst., vol. 5, pp. 212-222.

WATT, J.

1955 Territory threat display of the black oystercatcher. Notornis, vol. 6, no. 6, p. 175 .

WEBSTER, J. D.

1941 a The breeding of the black oyster-catcher. Wilson Bull., vol. 53, no. 3, pp. 141-156.

$1941 \mathrm{~b}$ Feeding habits of the black oyster-catcher. Condor, vol. 43, no. 4, pp. 175-180. 


